GEOLOGICAL SURVEY CIRCULAR 260

\title{
STRATIGRAPHIC SECTIONS OF THE \\ PHOSPHORIA FORMATION IN \\ MONTANA. 1948
}

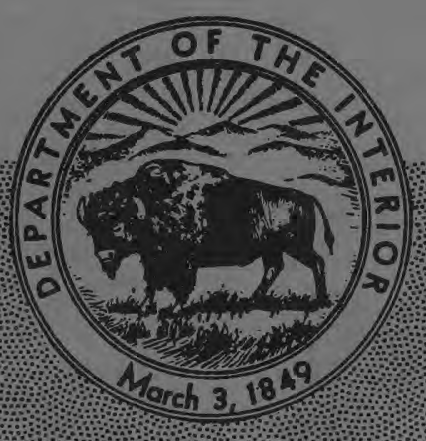


UNITED STATES DEPARTMENT OF THE INTERIOR

Douglas McKay, Secretary

GEOLOGICAL SURVEY

W. E. Wrather, Director

GEOLOGICAL SURVEY CIRCULAR 260

\section{STRATIGRAPHIC SECTIONS OF THE PHOSPHORIA FORMATION IN MONTANA, 1948}

By M. R. Klepper, F. S. Honkala, O. A. Payne, and E. T. Ruppel

This report concerns work done partly on behalf of the U. S. Bureau of Reclamation and partly on behalf of the U.S. Atomic Energy Commission, and is published with the permission of the Commission. 


\title{
STRATIGRAPHIC SECTIONS OF THE PHOSPHORIA FORMATION IN MONTANA, 1948
}

\author{
By M. R. Klepper, F. S. Honkala, O. A. Payne, and E. T. Ruppel
}

CONTENTS

Lot no. Page

Lot no. Page

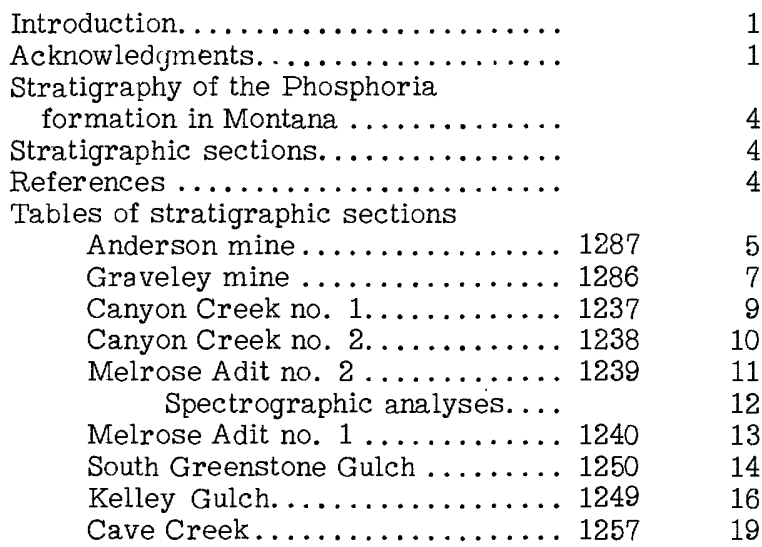

Tables of stratigraphic sections-Continued Cedar Creek. ................ 1256

Sawtooth Peak............. $1241 \quad 23$

Upper French Creek. . . . . . . . . $1248 \quad 27$

Wadham Springs ..........1246-1247 28

Centennial Range

Trench no. $4 \ldots \ldots \ldots \ldots \ldots \ldots . \ldots 1251 \quad 31$

Odell Creek............... $1252 \quad 32$

Centennial Range

Trench no. $1 \ldots \ldots \ldots \ldots \ldots \ldots 1253 \quad 34$

Centennial Range

Trenches

nos 2 and $3 \ldots \ldots \ldots \ldots$ 1254-1255 36

Additional analyses of

sample OAP-505........ 38

Luke mine............... 1285

\section{ILLUSTRATIONS}

Figure 1. Outcrop of the Phosphoria formation in Montana and localities sampled..................

2. Generalized section of the Phosphoria formation at Sheep Creek (lot no. 1234$) \ldots \ldots \ldots \ldots \ldots \ldots \ldots \ldots \ldots \ldots$

\section{INTRODUCTION}

The U. S. Geological Survey has measured and sampled the Phosphoria formation at many localities in Montana and other western states. These data will not be fully synthesized and analyzed for several years, but segments of the data, accompanied by little or no interpretation, are published as preliminary reports as they are assembled. This report, which contains abstracts of many of the sections in southwestern Montana (fig. 1), is one of this series and is the second report of data gathered in Montana during 1948. The field and laboratory procedures adopted in these investigations are described rather fully in a companion report (McKelvey and others, 1953).

Many people have taken part in this investigation. The program of which this work is a part was organized by V. E. McKelvey. D. A. Bostwick, E. R. Cressman, J. E. Joyce, J. A. Kelleher, R. I. Konizeski, R. L. Parker, L. A. Thomas, and W. H. Wilson participated in the description of strata and collection of samples referred to in this report. The laboratory preparation of samples for chemical analysis was done in Denver, Colo., under the direction of W. P. Huleatt.

All the $\mathrm{P}_{2} \mathrm{O}_{5}, \mathrm{~F}, \mathrm{~V}_{2} \mathrm{O}_{5}$, and acid-insoluble analyses and some of the $\mathrm{Al}_{2} \mathrm{O}_{3}, \mathrm{Fe}_{2} \mathrm{O}_{3}$, and loss-on- ignition analyses were made.for the Survey by the U. S. Bureau of Mines at the Northwest Electrodevelopment Laboratory, Albany, Oreg., under the supervision of S. M. Shelton and M. L. Wright. The spectrographic analyses were made by D. M. Mortimer, also in this laboratory. Most of the $\mathrm{Al}_{2} \mathrm{O}_{3}, \mathrm{Fe}_{2} \mathrm{O}_{3}$, and loss-on-ignition analyses were made in the Trace Elements Section laboratory of the Survey in Washington, D. C. , under the direction of J. C. Rabbitt, by chemists I. Barlow, A. B. Caemmerer, J. L. Greene, and N. Guttag.

Compilation of the data has been largely by R. P. Sheldon and F. D. Frieske under the supervision of R. W. Swanson. Organization of the tabular data has been largely by Anita Cozzetto.

\section{ACKNOWLEDGMENTS}

Special thanks are due A. E. Weissenborn, who gave much advice and help in carrying out the field program. The cost of the field and laboratory investigations has been borne partly by the Missouri River Basin Division of the Bureau of Reclamation and the Division of Raw Materials of the Atomic Energy Commission. 


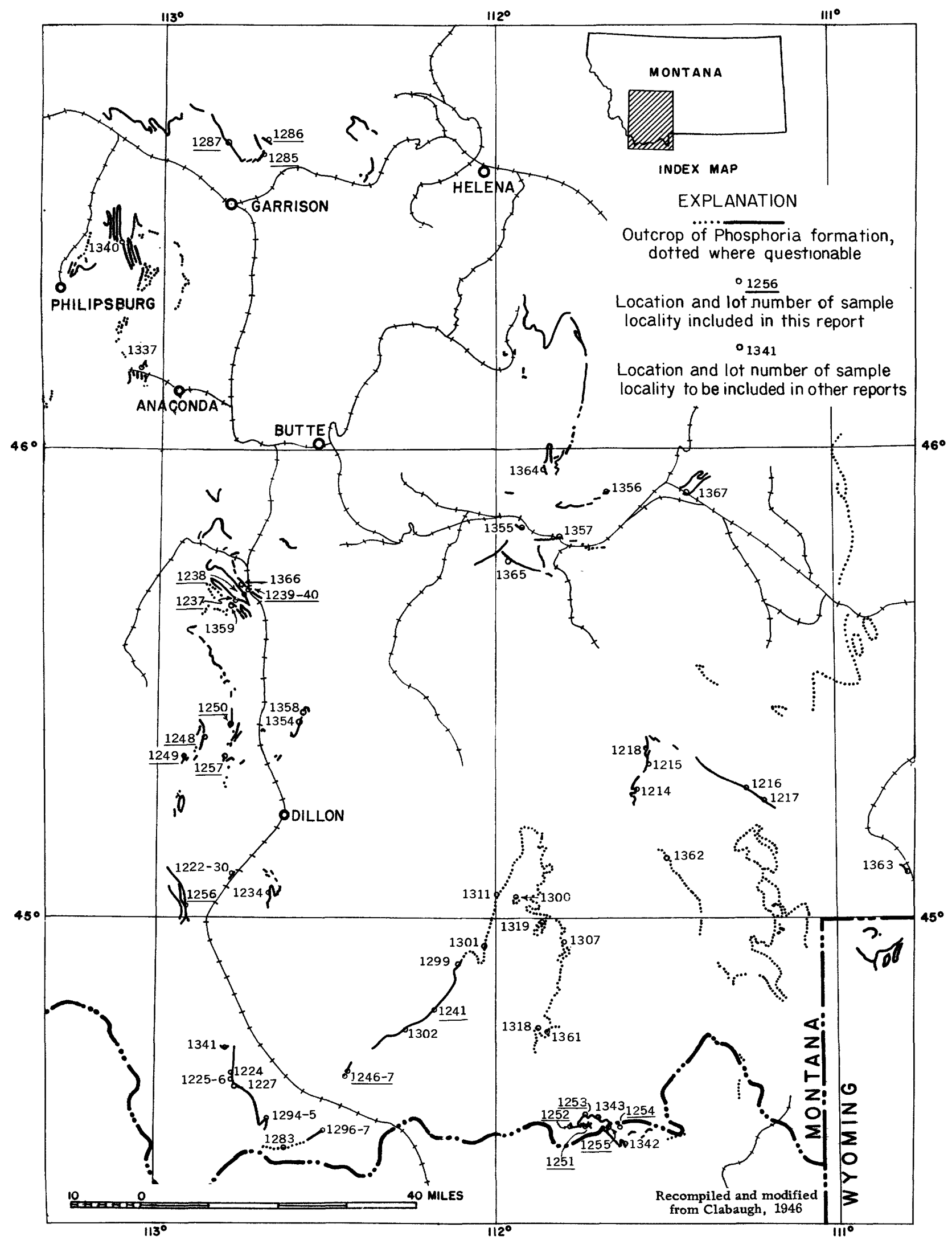

Figure 1.-Outcrop of the Phosphoria formation in Montana and localities sampled. 


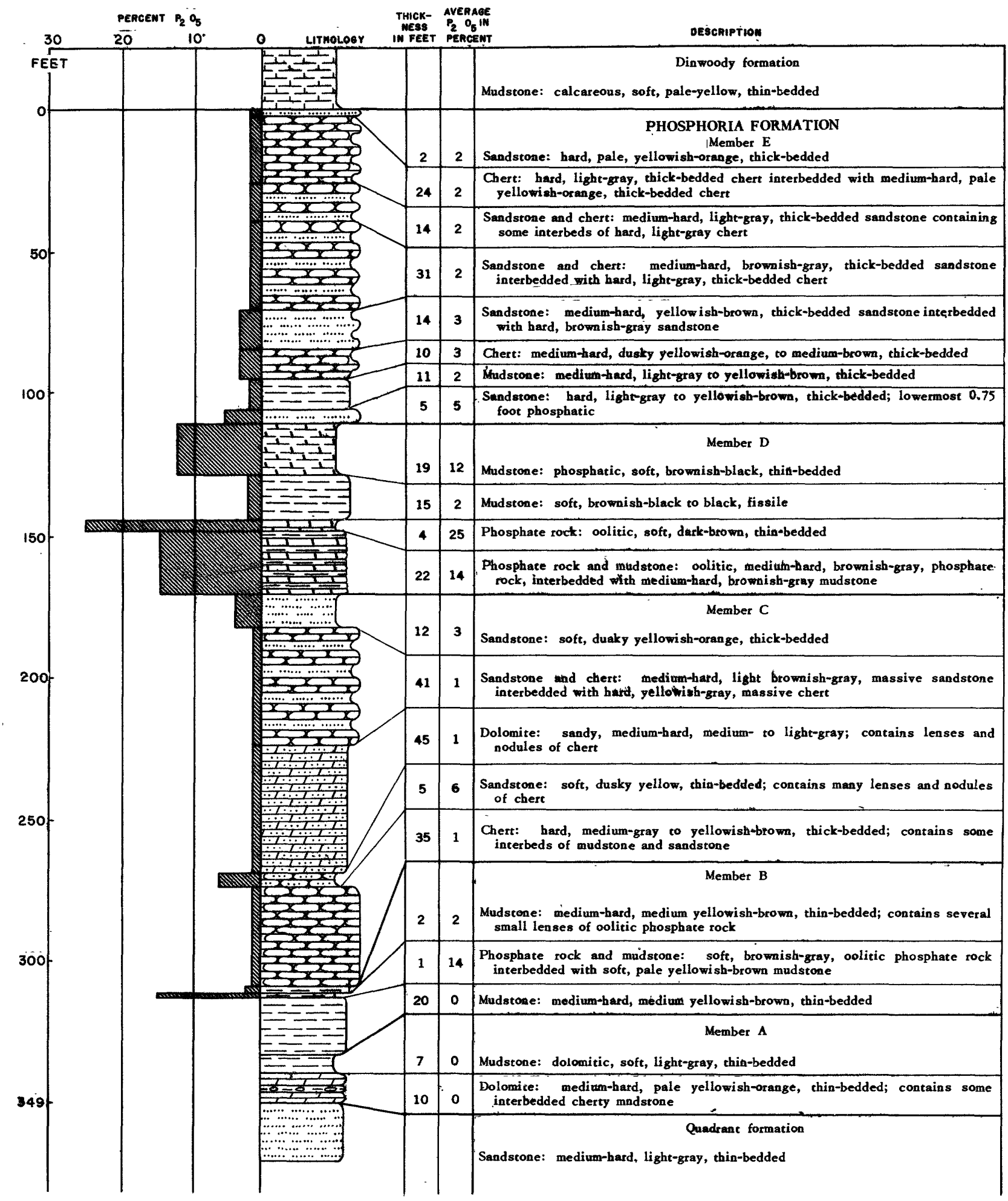

Figure 2. -Generalized section of the Phosphoria formation at Sheep Creek (lot no. 1234). 
It is a pleasure to acknowledge the fine cooperation extended to the field parties by the local residents, property owners, and operating companies who furnished information and services and gave access to property. These include principally R. B. Shelledy, R. J. Armstrong, and J. J. McKay, of the Montana Phosphate Products Co., and William Anderson and the Martin brothers who developed the Melrose and Canyon Creek properties.

\section{STRATIGRAPHY OF 'THE PHOSPHORIA FORMATION IN MONTANA}

The Phosphoria formation in southwestern Montana consists in general of five members, two phosphatic shale members and three hard members (fig. 2). The lower two hard members are dominated by limestone, the top member by chert and sandstone or quartzite. Most of the members can be identified over a large part of the area of outcrop, although correlation toward the east and northeast is difficult. The formation ranges in thickness from less than 100 feet to more than 800 feet.

The lowermost, or A, member is thickest toward the west and southwest-with a maximum thickness of nearly 350 feet-and consists of limestone or dolomite, sandstone, mudstone, and chert. It overlies the Quadrant formation of Pennsylvanian age and is probably equivalent to the upper member of the Wells formation of southeastern Idaho and adjacent Wyoming and Utah (McKelvey, 1949).

The lower phosphatic shale member, or $B$, is about 50 feet thick near the southwest corner of the state but thins markedly to the north and east, where
Element

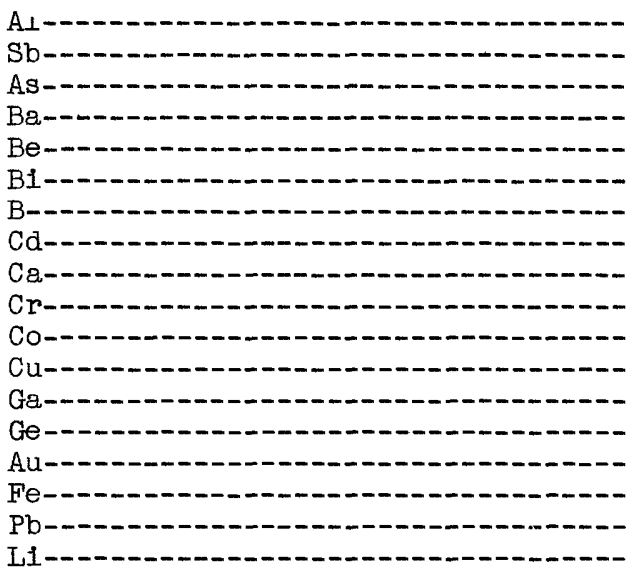

Percent

\section{REFERENCES}

Clabaugh, P. S., 1946, Permian phosphate deposits of Montana, Idaho, Wyoming, and Utah: U. S. Geol. Survey, Strategic Minerals Inv. Preliminary Ma p 3-198.

McKelvey, V..E., 1949, Geological studies of the western phosphate field: Am. Inst. Min. Met. Eng. Mining Trans., v. 184, p. 270-279.

in some areas it cannot be recognized. It contains a rich bed of minable phosphate in the Centennial Range.

The middle, or $\mathrm{C}$, member consists of as much as 200 feet of limestone with some chert and sandstone. The upper phosphatic shale, or $\mathrm{D}$, member is rather similar to and much more uniform and widespread than the B member, though minable phosphate is present only toward the northend of the area (plate 1), where the full thickness of the phosphatic zone may consist of a single 3 - to 5-foot bed of high-grade phosphate rock.

The uppermost, or $\mathrm{E}$, member is the most widespread and uniform, averaging about 100 feet in thickness and consisting chiefly of siliceous rockssiltstone, chert, and quartzitic sandstone. It is overlain by the Dinwoody formation of Triassic age in the greater part of the area and by the Ellis group of Jurassic age toward the north and northeast.

\section{STRATIGRAPHIC SECTIONS}

Analytical data and abstracts of stratigraphic sections measured at 20 localities follow. Their locations as well as those of other sections previously reported (Swanson and others, 1953) and sections to be reported later are shown on figure 1 .

The semiquantitative spectrographic analyses are based upon comparisons with a standard plate representing known quantities of the elements tested for and made at the same exposure. Greater sensitivities for many elements can be obtained by additional exposures. The standard sensitivities for the elements noted in this report are as follows:

Element

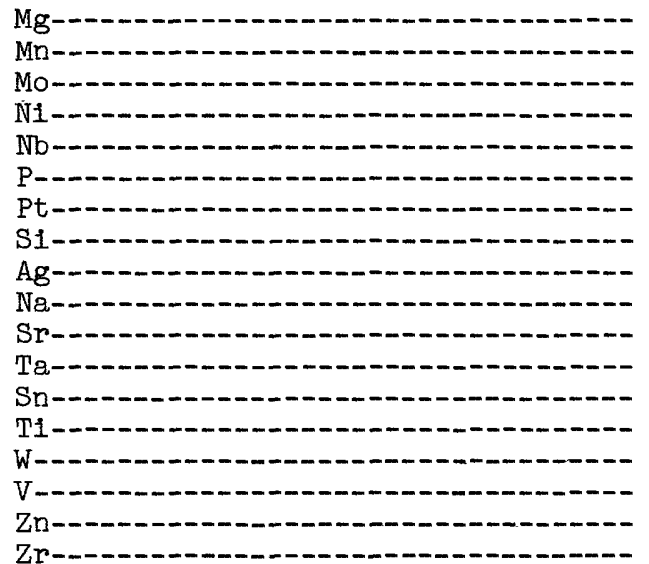

Percent

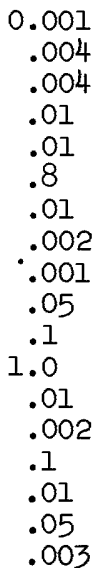

McKelvey, V. E., Davidson, D. F., O'Malley, F. W., and Smith, L. E., 1953, Stratigraphic sections of the Phosphoria formation in Idaho, 1947-48, part 1: U. S. Geol. Survey Circ. 208. Swanson, R. W., Lowell, W. R., Cressman, E. R., and Bostwick, D. A., 1953, Stratigraphic sections of the Phosphoria formation in Montana, 1947-48: U. S. Geol. Survey Circ. 209. 


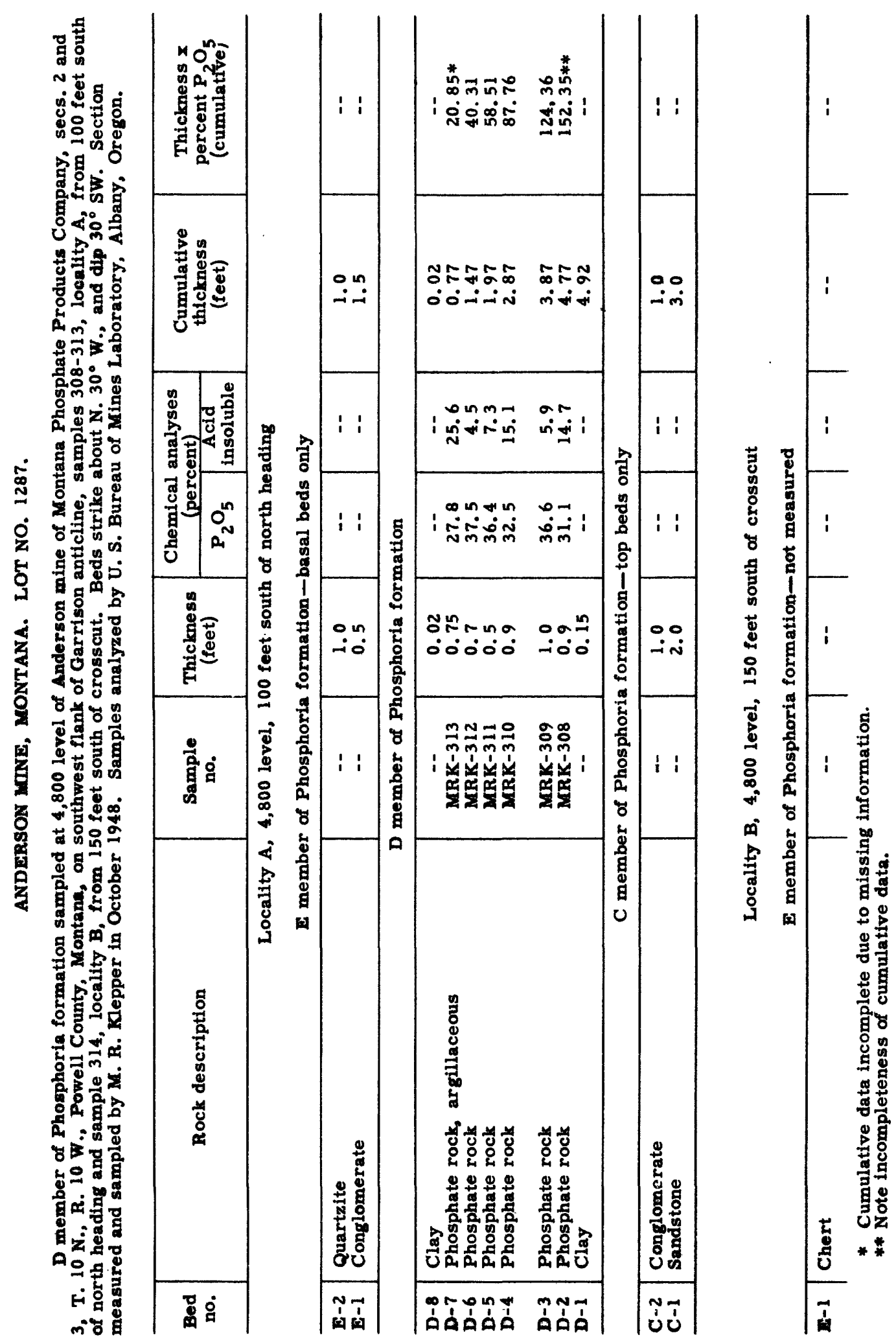




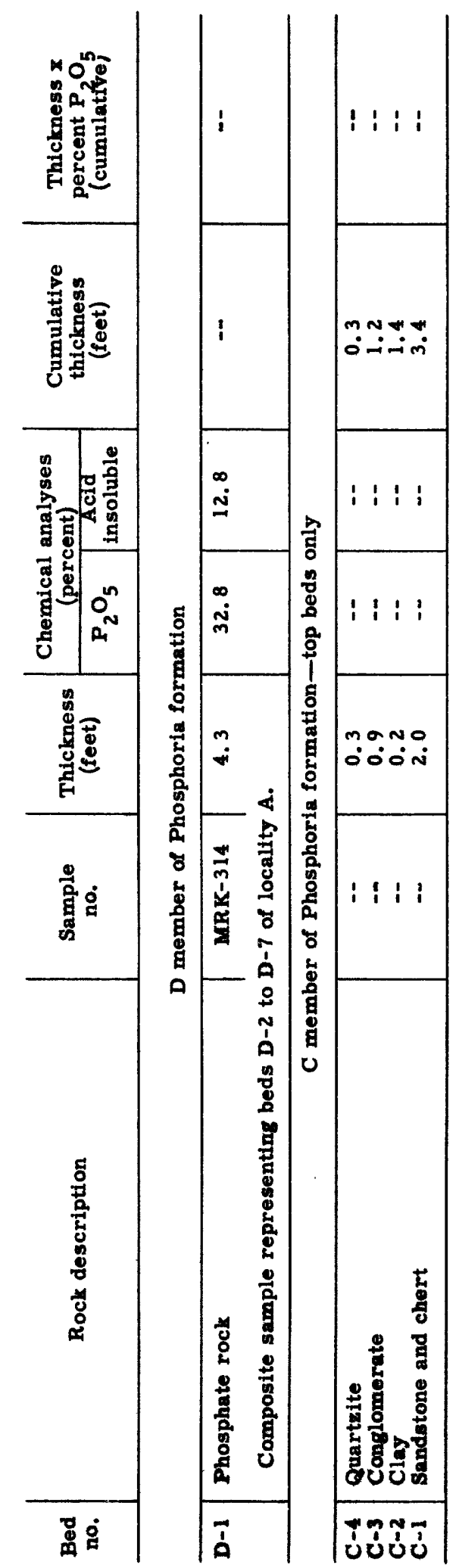



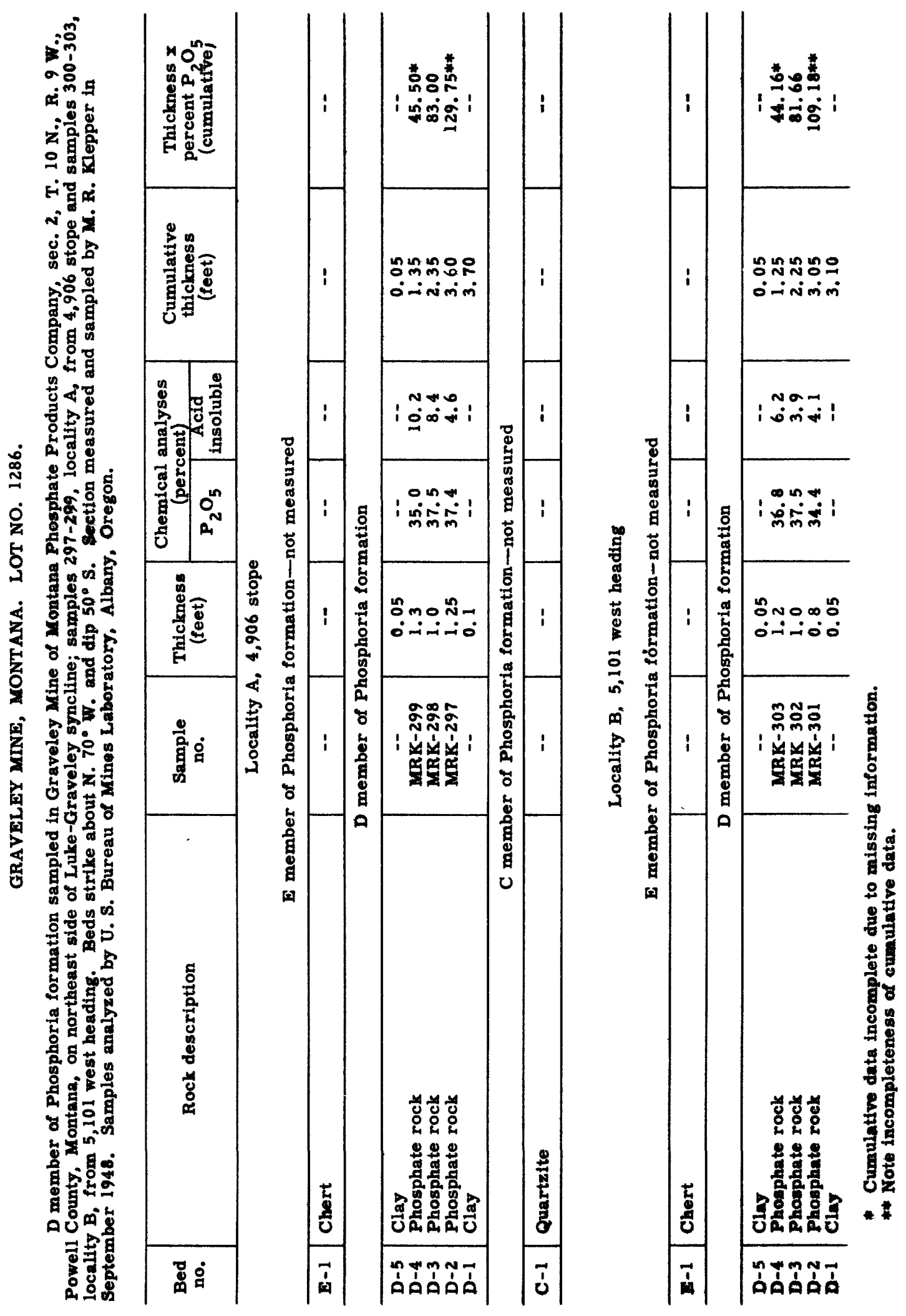


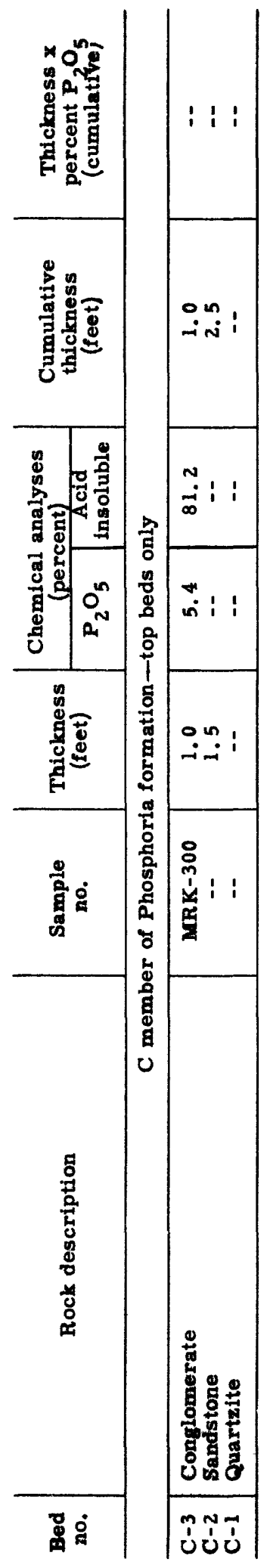




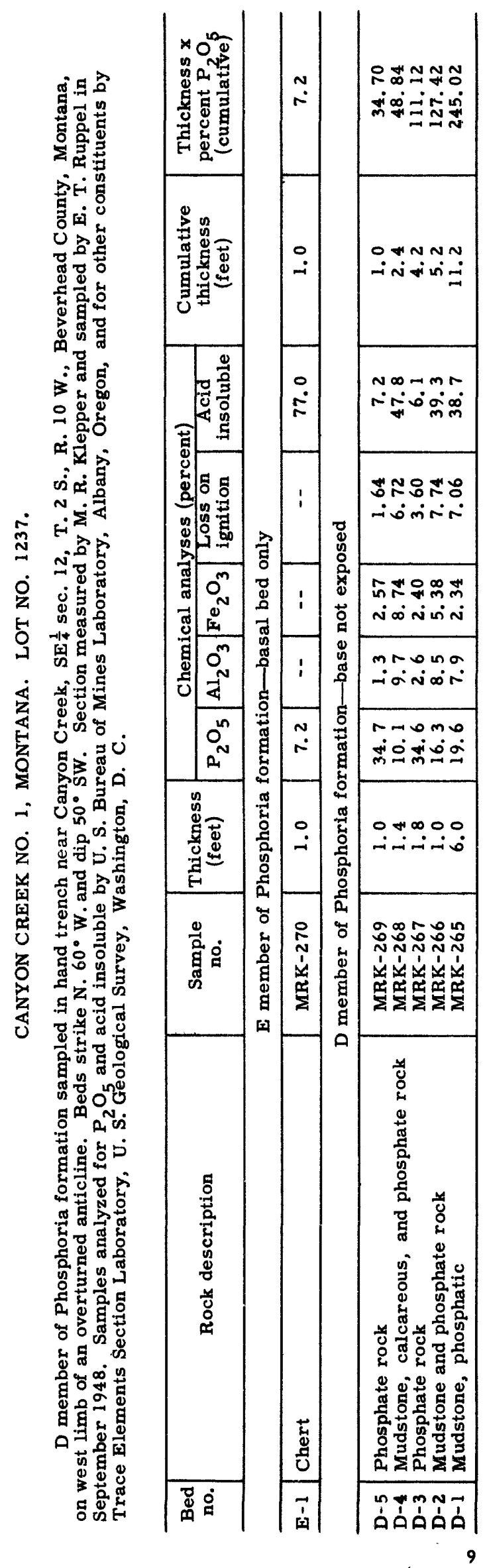




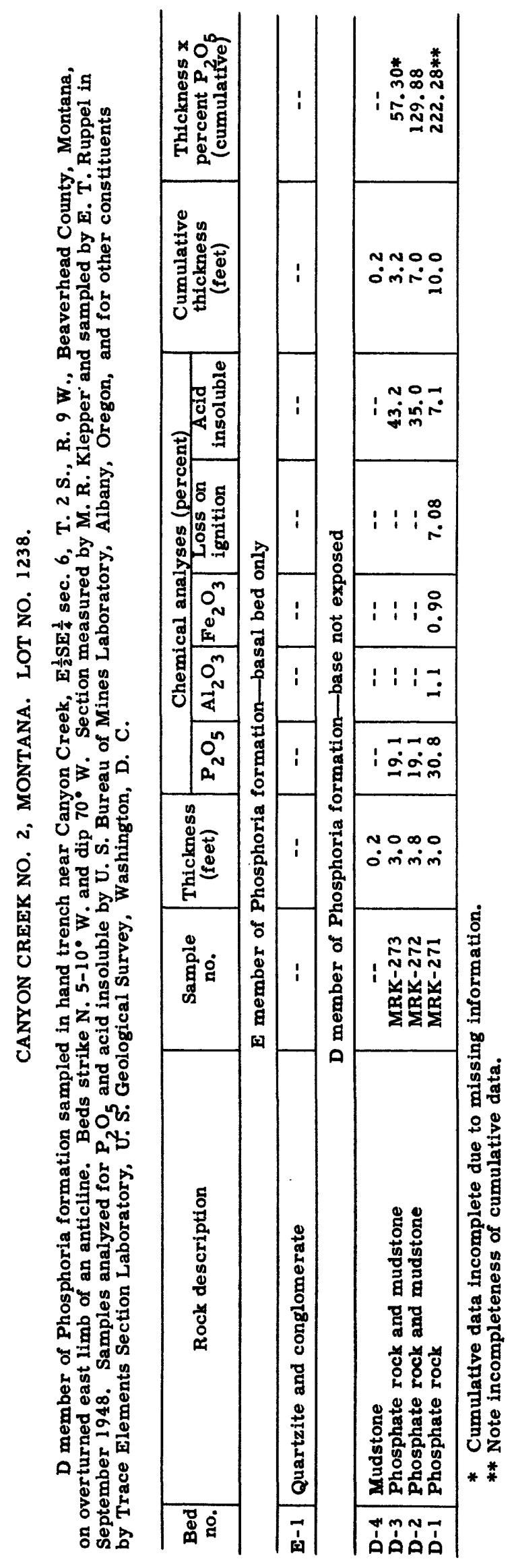




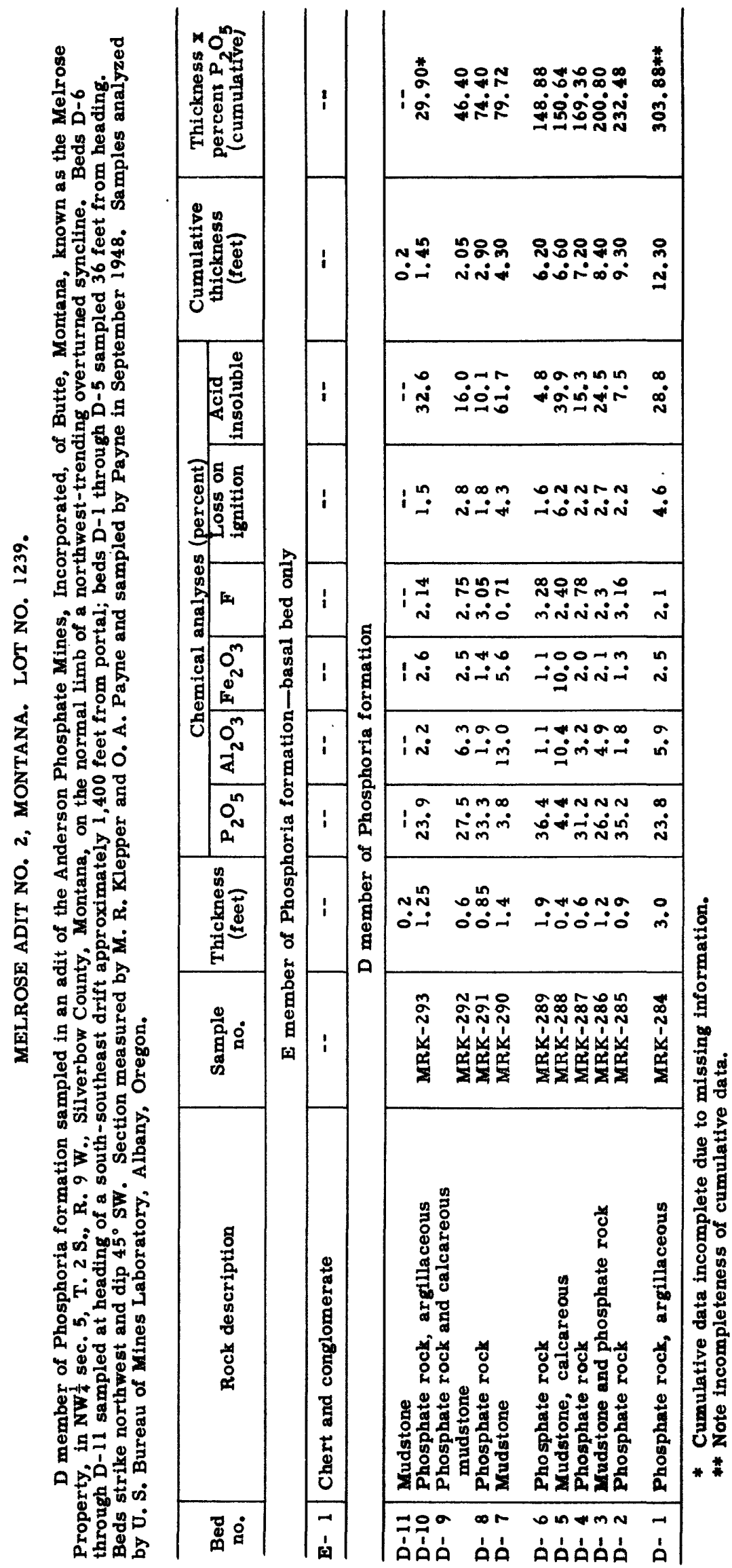




\begin{tabular}{|c|c|c|c|c|c|}
\hline & & 出 & 由日四四 & 因目咸白 & 国 \\
\hline 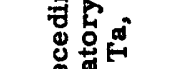 & & งี & 由四四回 & 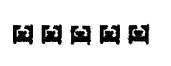 & (1) \\
\hline 国 & & $>$ & 口回的国盲 & AADA口 & A \\
\hline 过 & & $\vec{E}$ & UAคA & •คคค円 & A \\
\hline 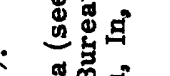 & & 㭊 & 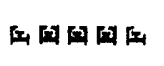 & 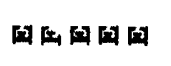 & (1) \\
\hline 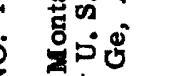 & & 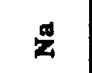 & 由国国自 & 由因田国 & 日 \\
\hline ك & & $\infty$ & ט ש ש ש ט & 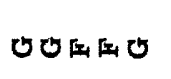 & 0 \\
\hline 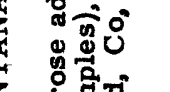 & 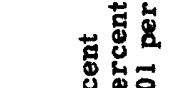 & $\vec{n}$ & $490<4$ & 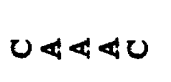 & 4 \\
\hline 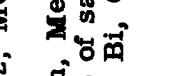 & $\begin{array}{l}2=0 \\
-0.0 \\
-0.0\end{array}$ & 㐾 & 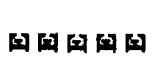 & 由口回回 & 由 \\
\hline 尊要 & 号 & $\stackrel{2}{\Sigma}$ & 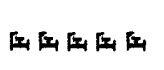 & 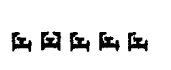 & is \\
\hline 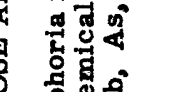 & $\begin{array}{ll} & \\
8 & \end{array}$ & $\underline{\Xi}$ & 由四四回 & 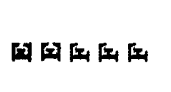 & 红 \\
\hline 跑察 & 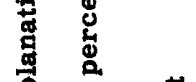 & $\stackrel{\infty}{\Sigma}$ & טטטטن & $A \& \cup \cup A$ & 0 \\
\hline 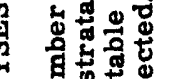 & 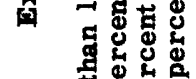 & $\stackrel{0}{*}$ & 4ण0ல & טنט ט & 0 \\
\hline A g & 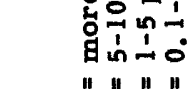 & $\ddot{U}$ & 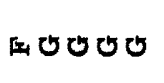 & ש ט ש ஏ ש & 0 \\
\hline 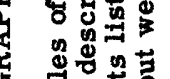 & & $\ddot{U}$ & 朋回四日 & 四口国回自 & A \\
\hline 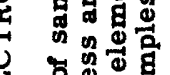 & & లే & $U \ll \varangle \& m$ & 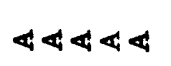 & $\varangle$ \\
\hline & & $\infty$ & 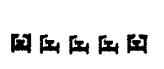 & 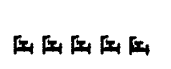 & s \\
\hline 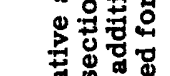 & & 7 & றலறலற & Uロறロ & m \\
\hline " & & 量。 & 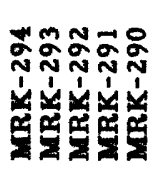 & 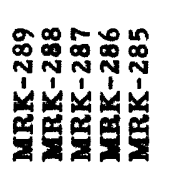 & 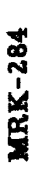 \\
\hline 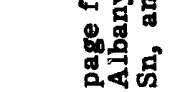 & & 宙 & 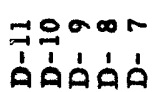 & 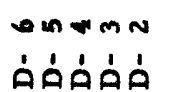 & $\dot{a}$ \\
\hline
\end{tabular}




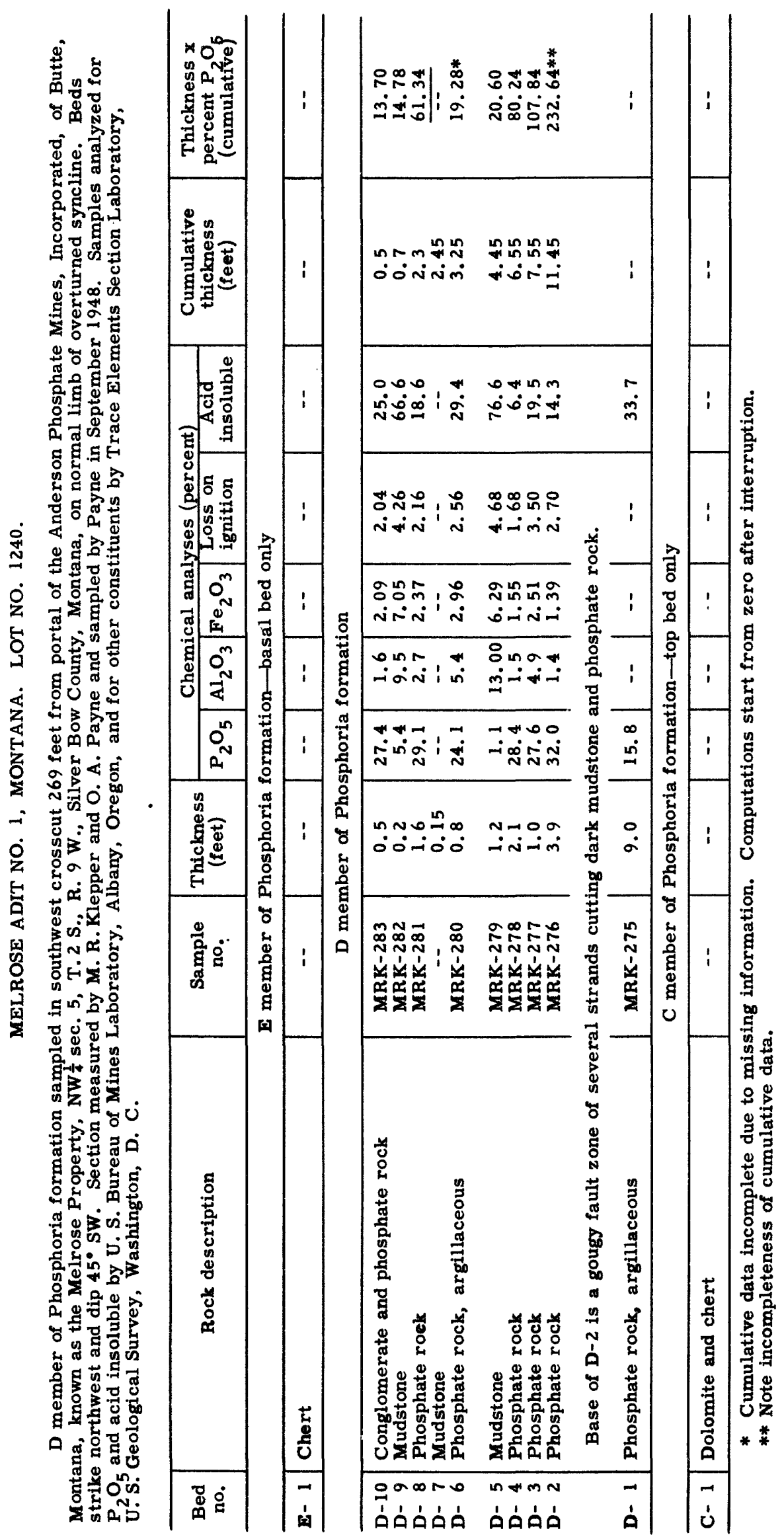




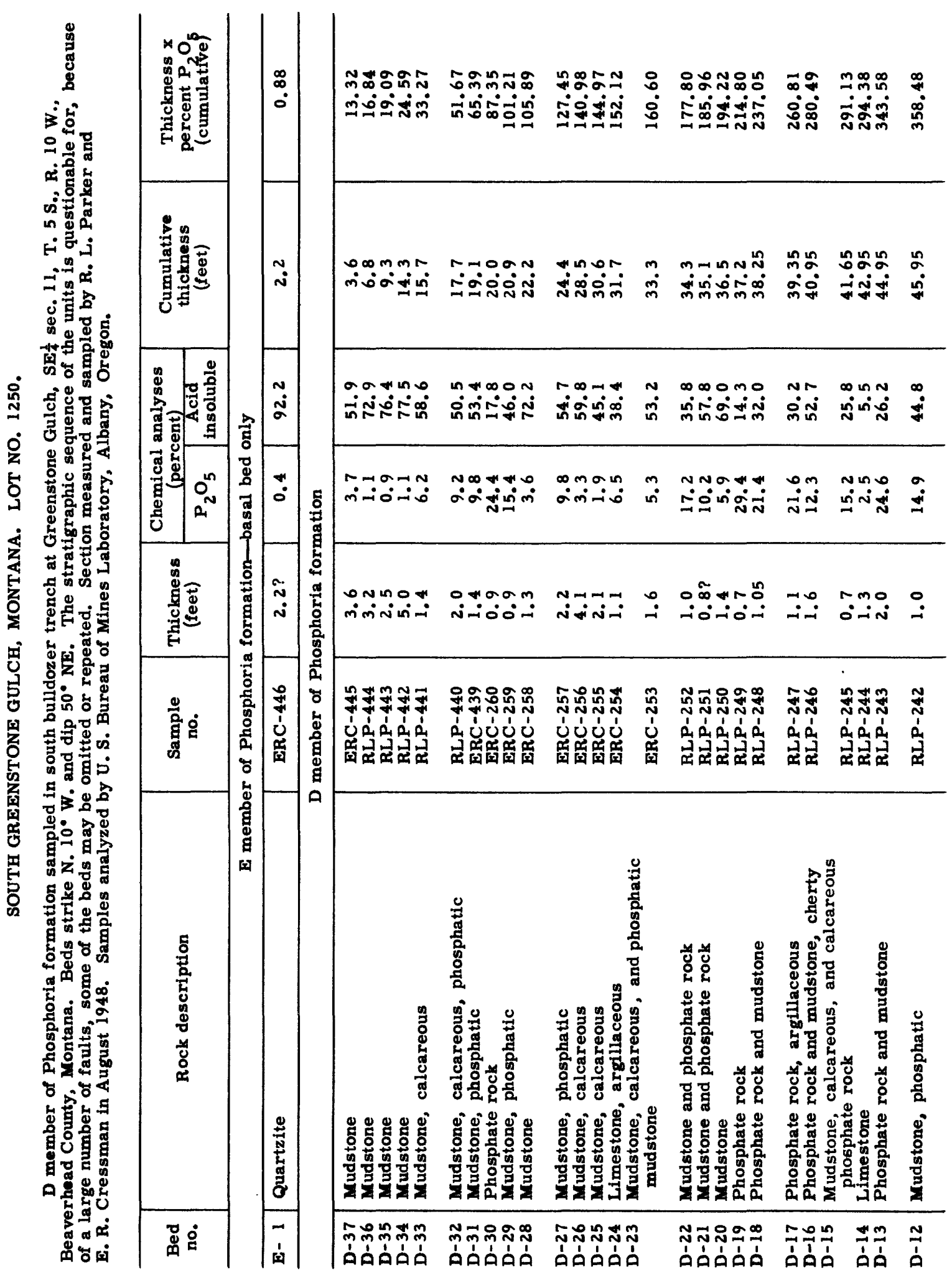




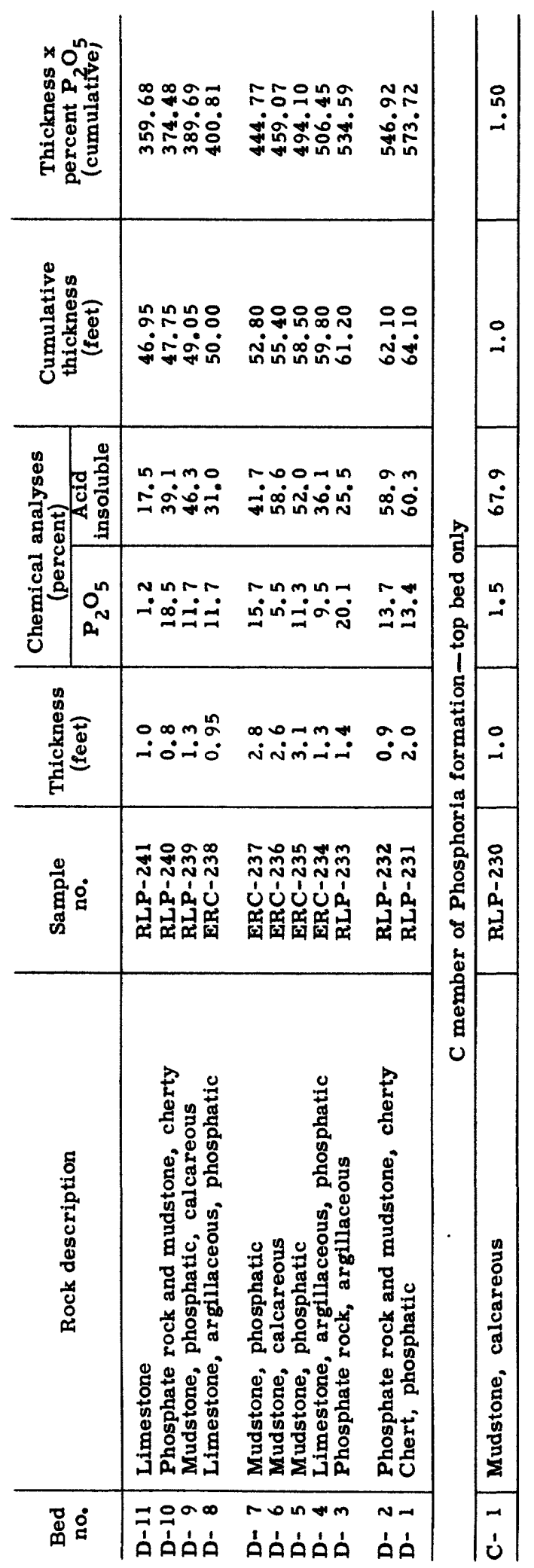




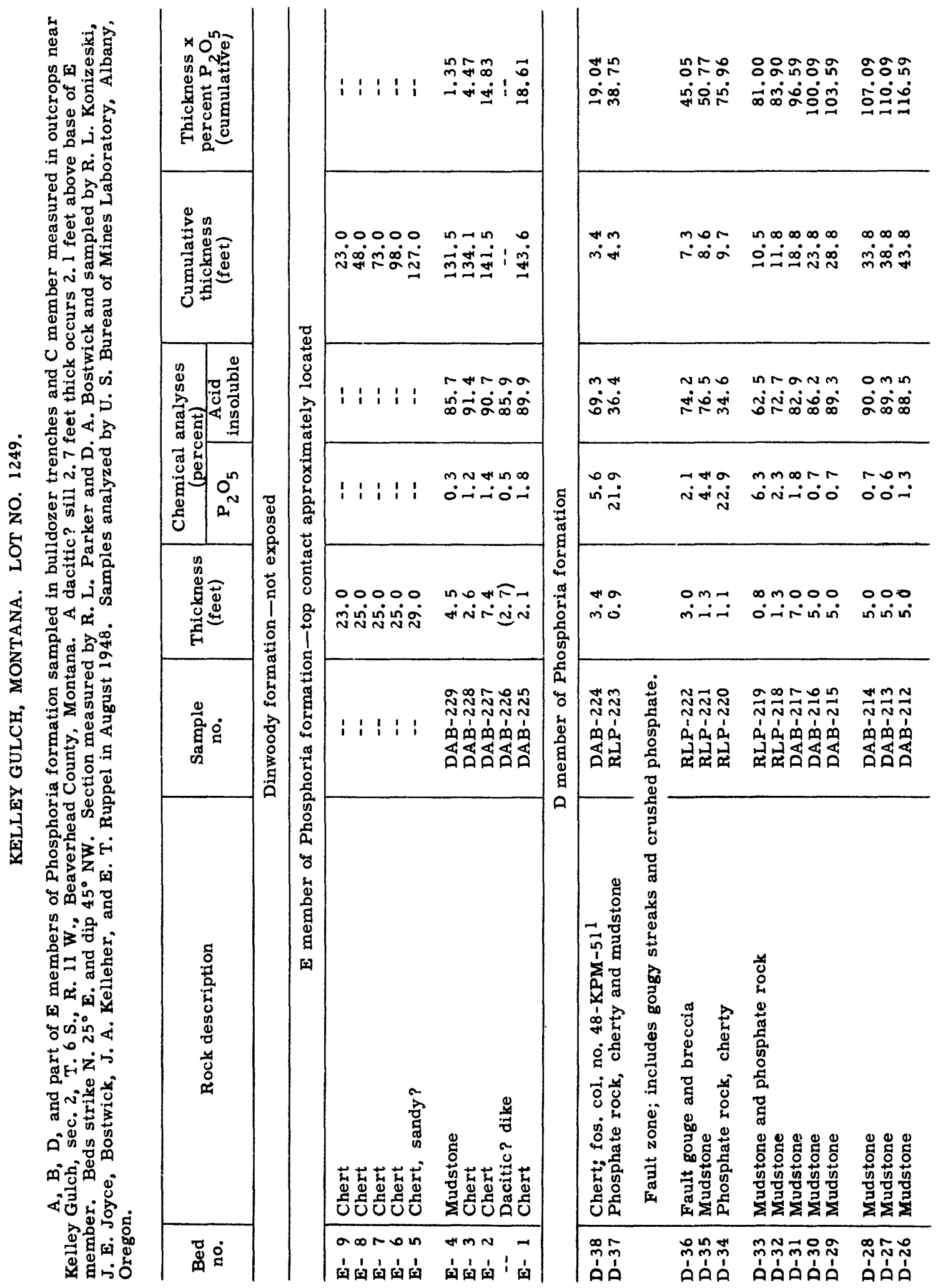




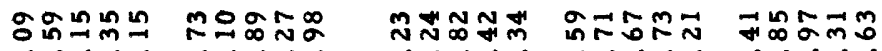

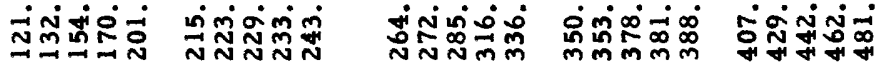

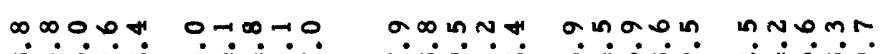

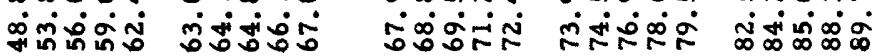

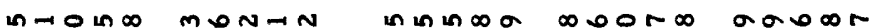

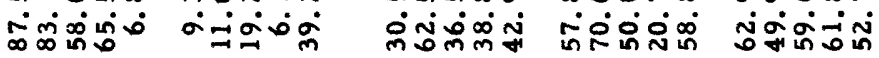

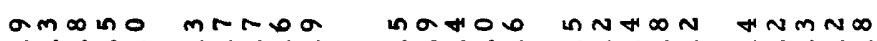

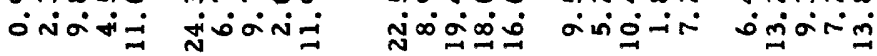

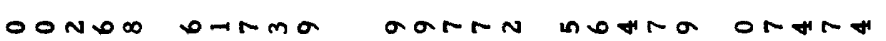

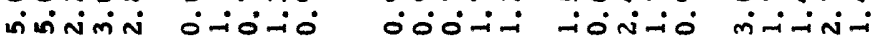

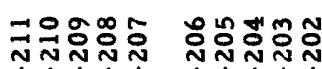

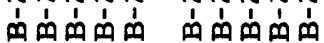

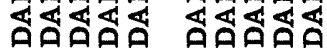

웅유

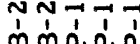

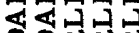

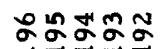
$\overrightarrow{1} \overrightarrow{1} \overrightarrow{1} \vec{\prime} \vec{\prime}$

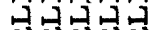

궁요 $\overrightarrow{1}=1 \rightarrow \frac{1}{1}=1$

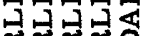

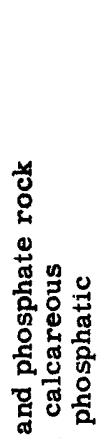

焉焉弯 起承官

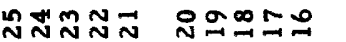

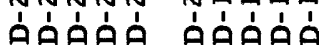
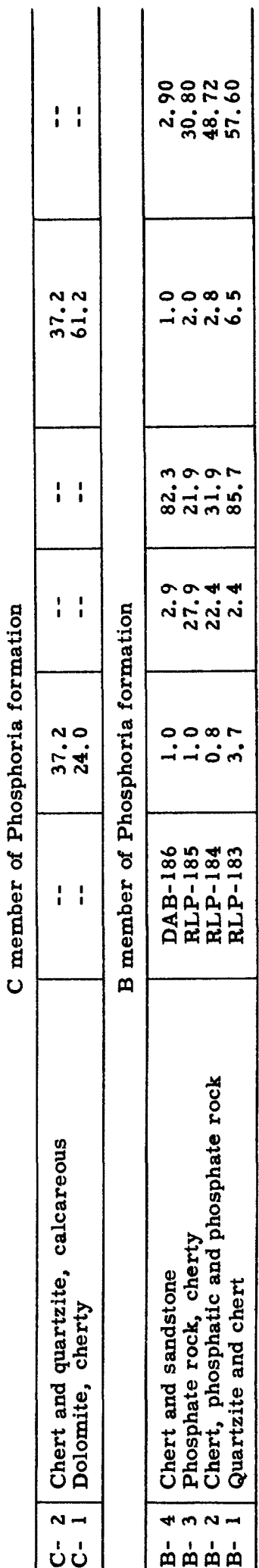

오ํํํํำ म요표

Noañ

0
0
0
0
07
0
0
0
0
0
0
0
0

un anto

ஸ்றீำ

- 岳

뭉ㅎㅎ $\overrightarrow{0}$

.

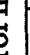

Nomm n $N$

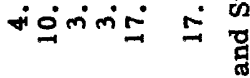

때유유

1'古古古

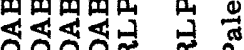

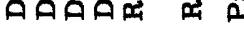




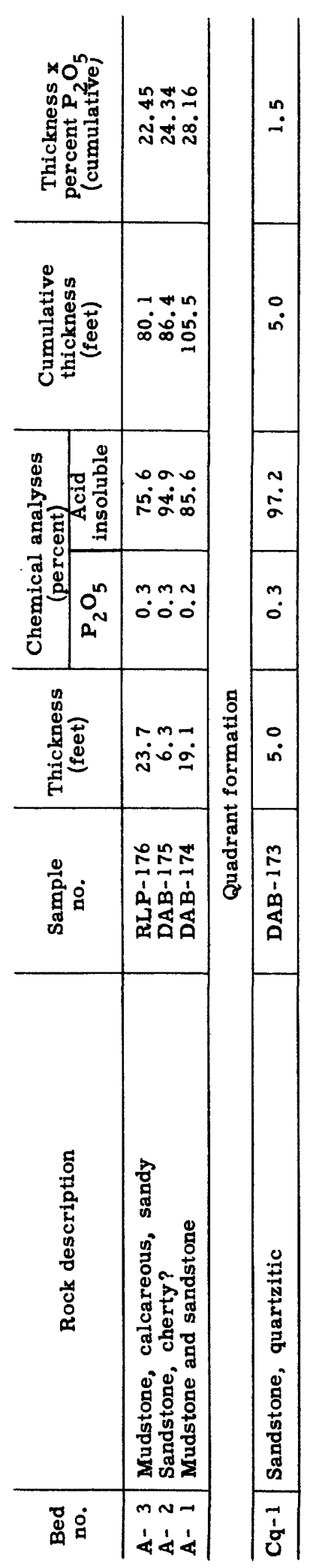




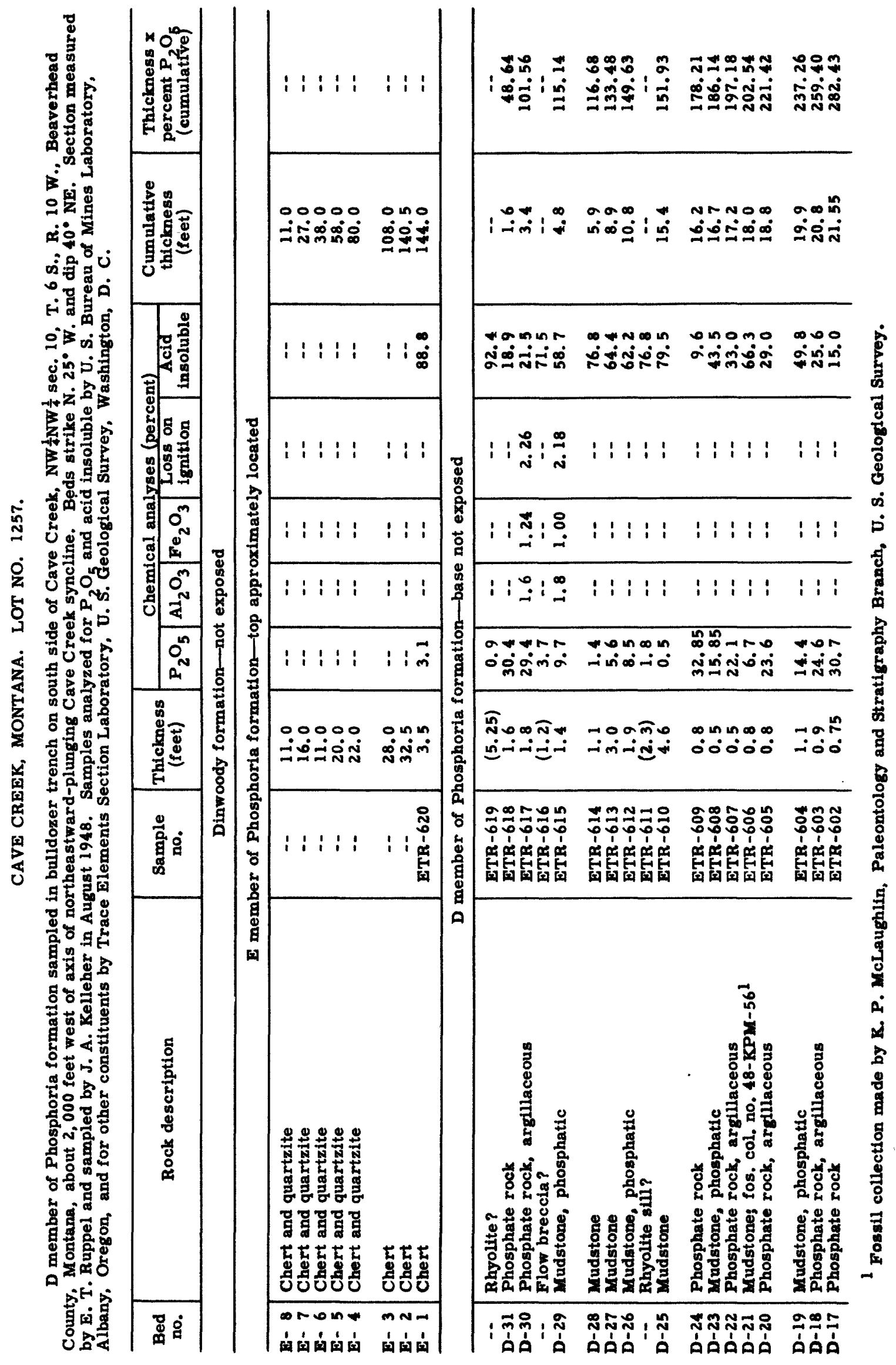




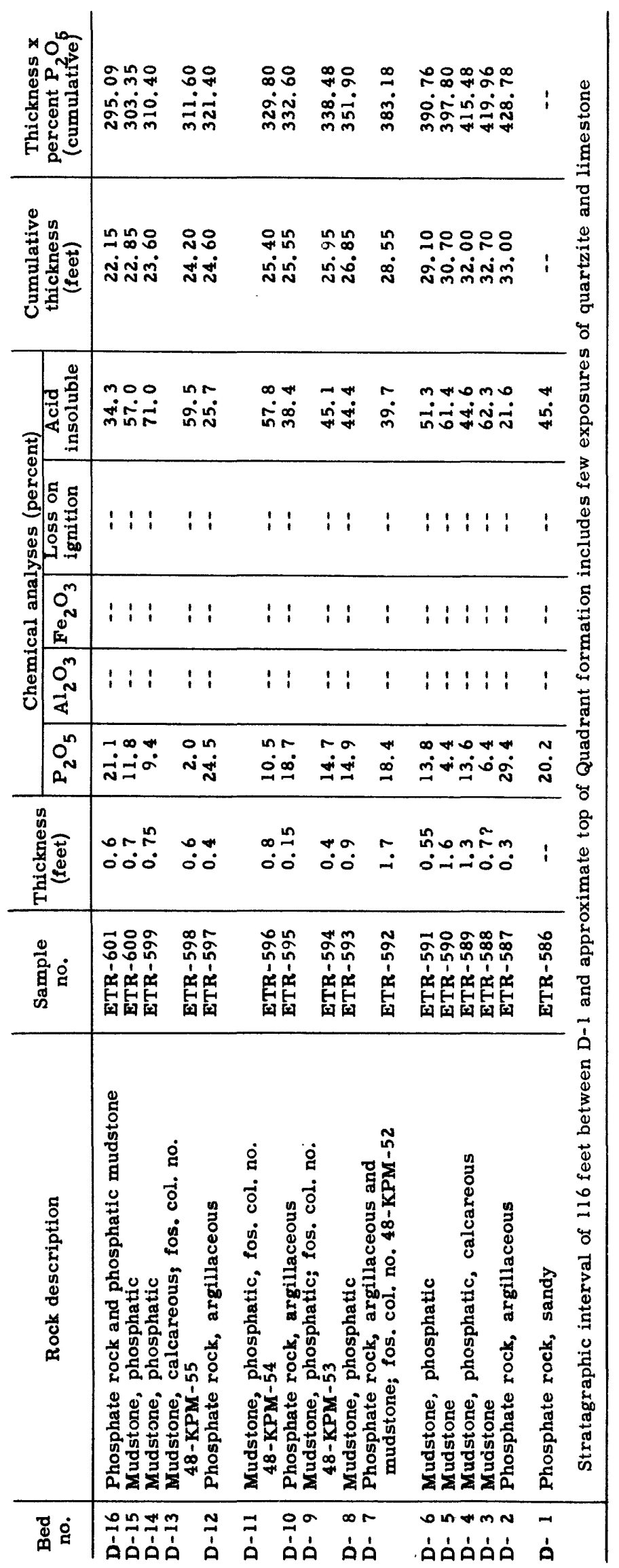




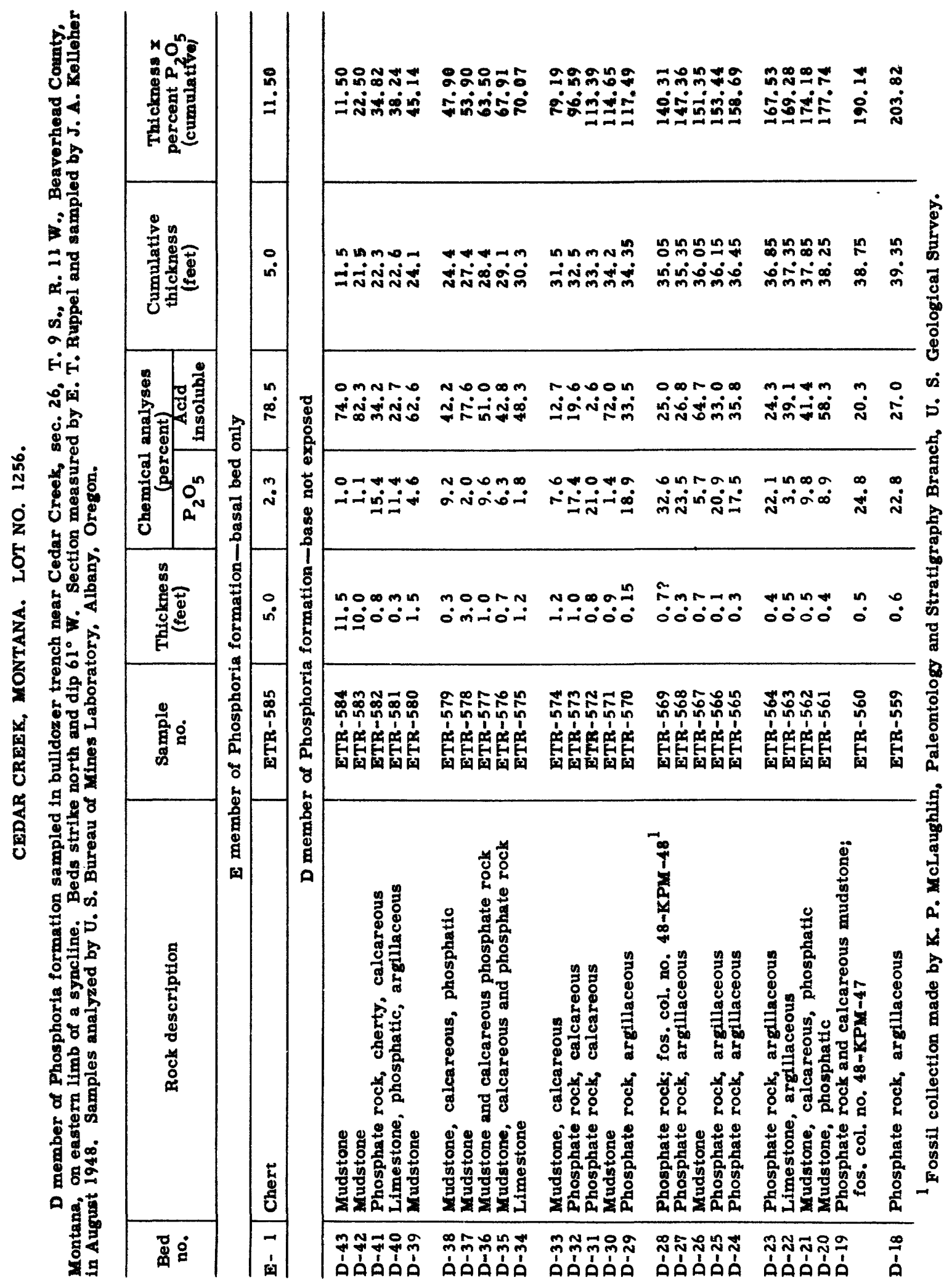




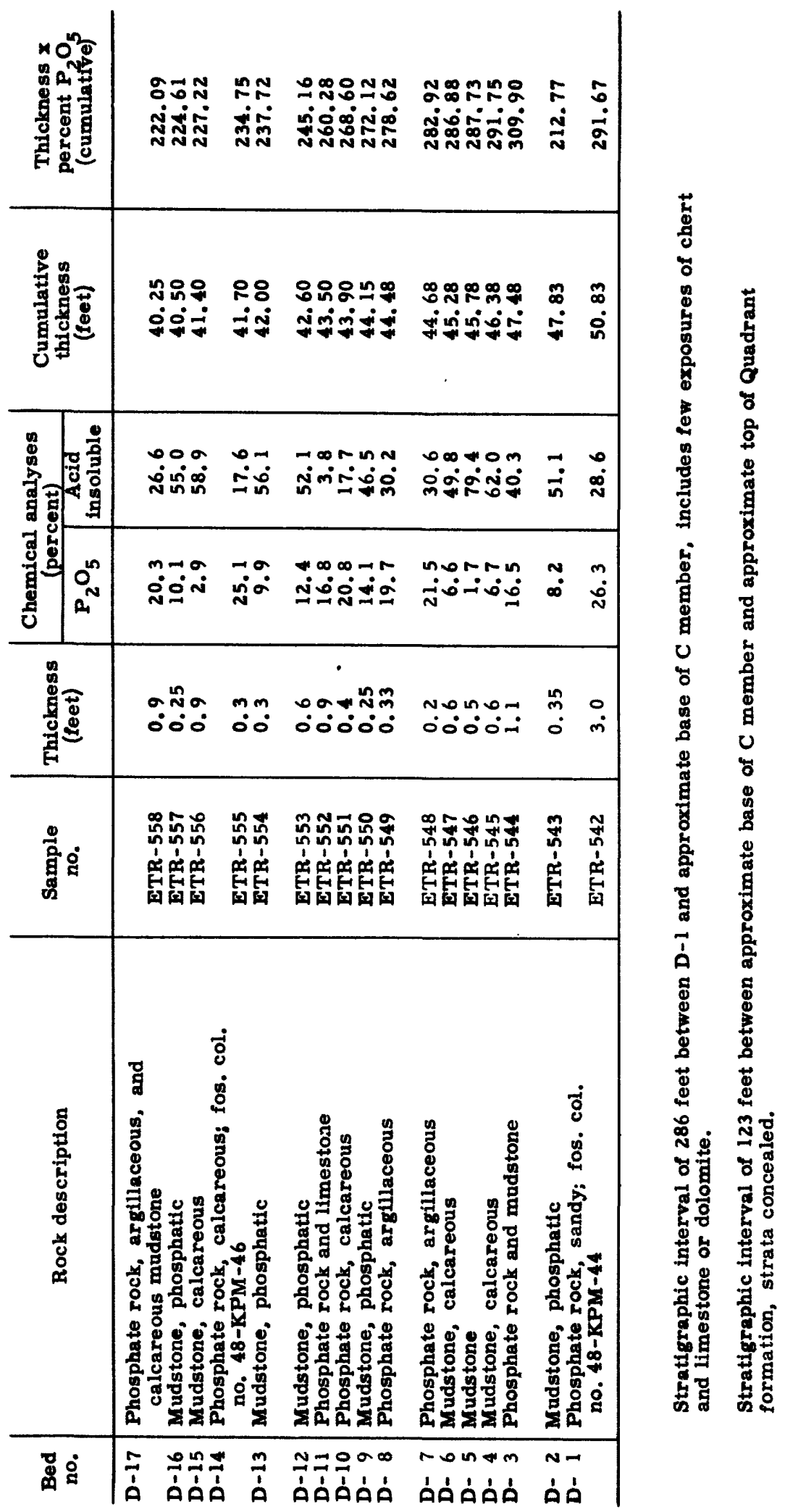




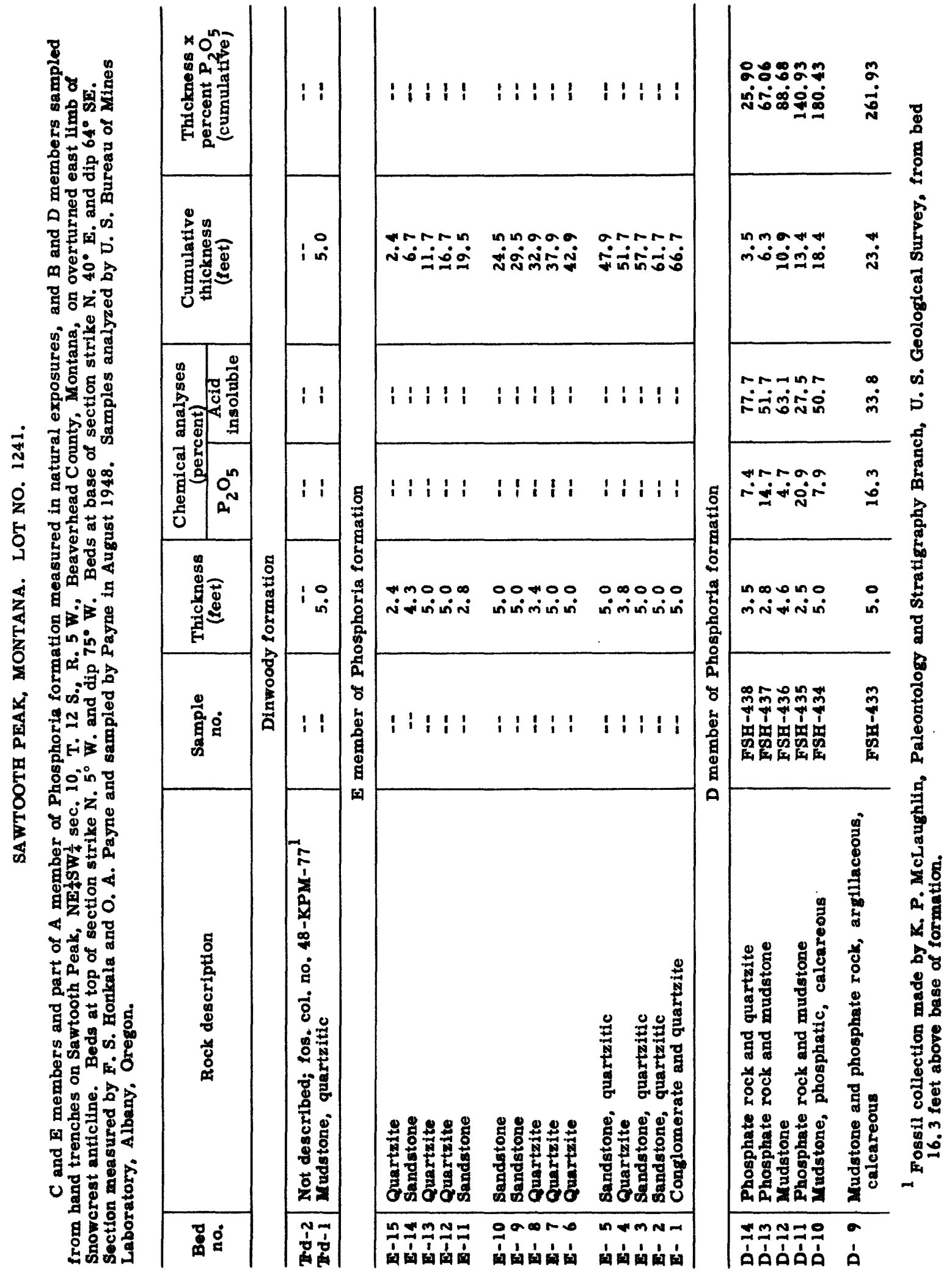




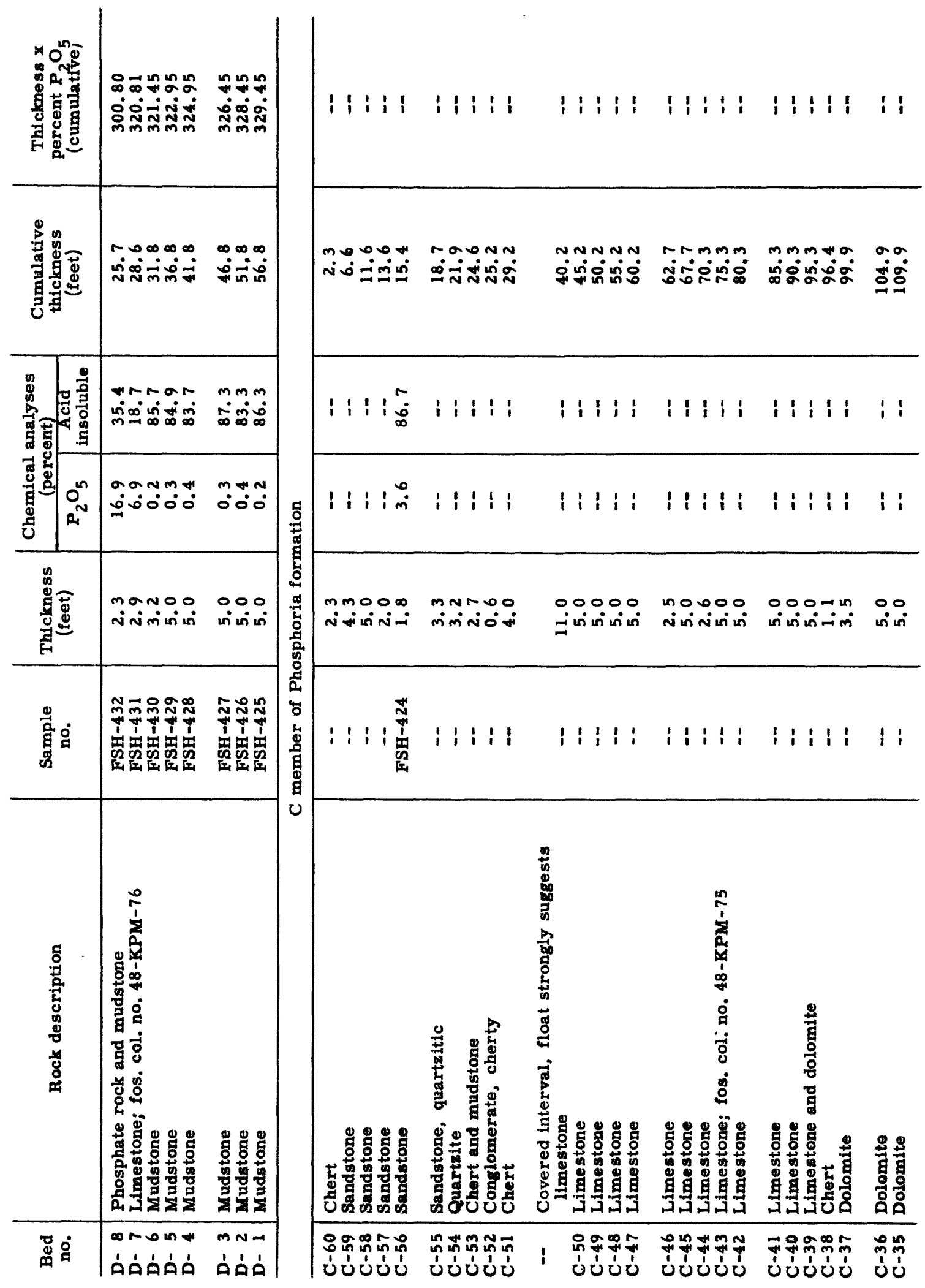




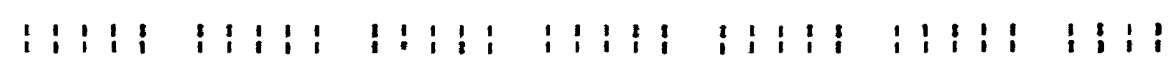

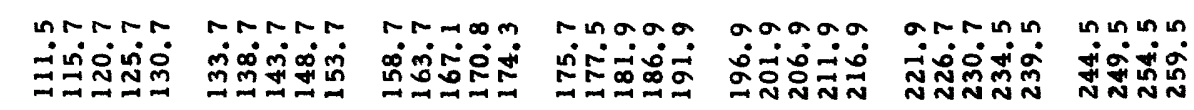

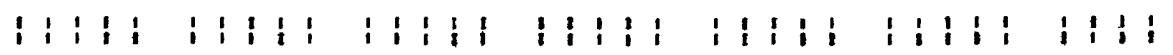

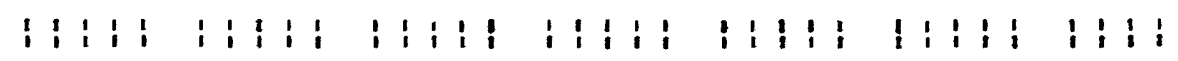

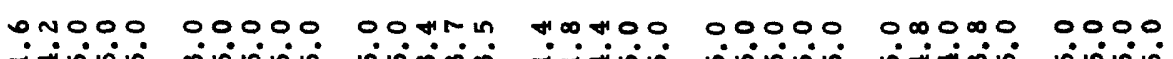

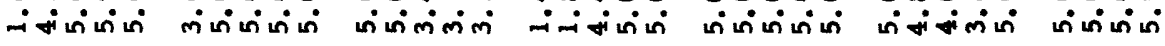

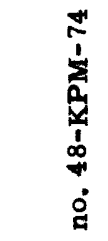

g.

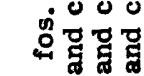

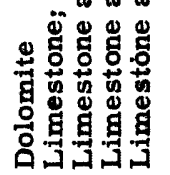

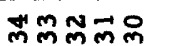
บับน์น์

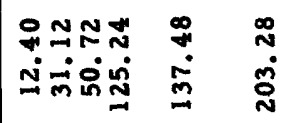

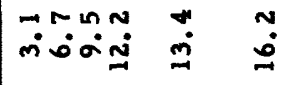

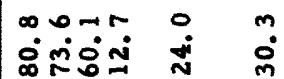

मñกำ

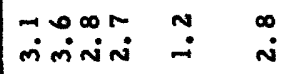

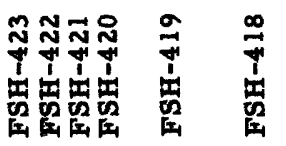

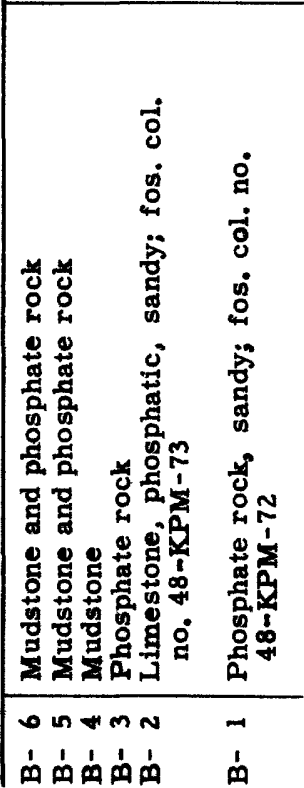




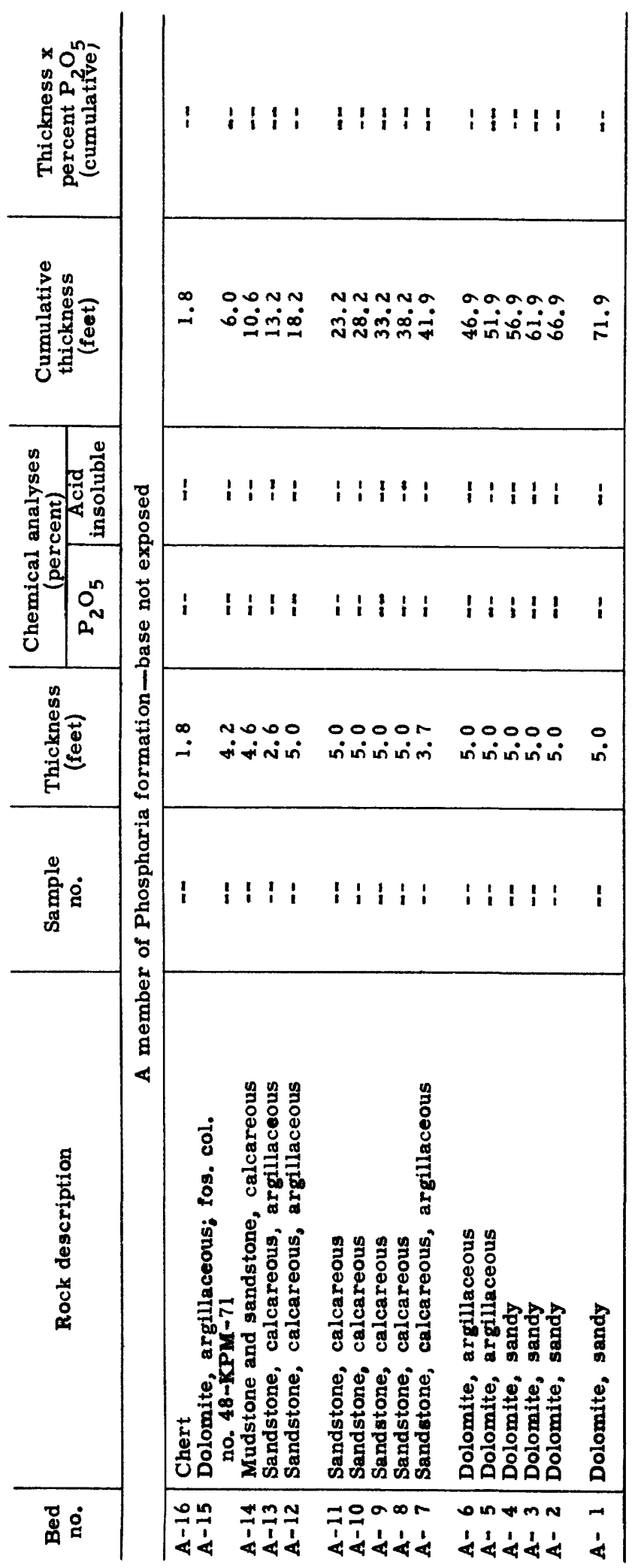




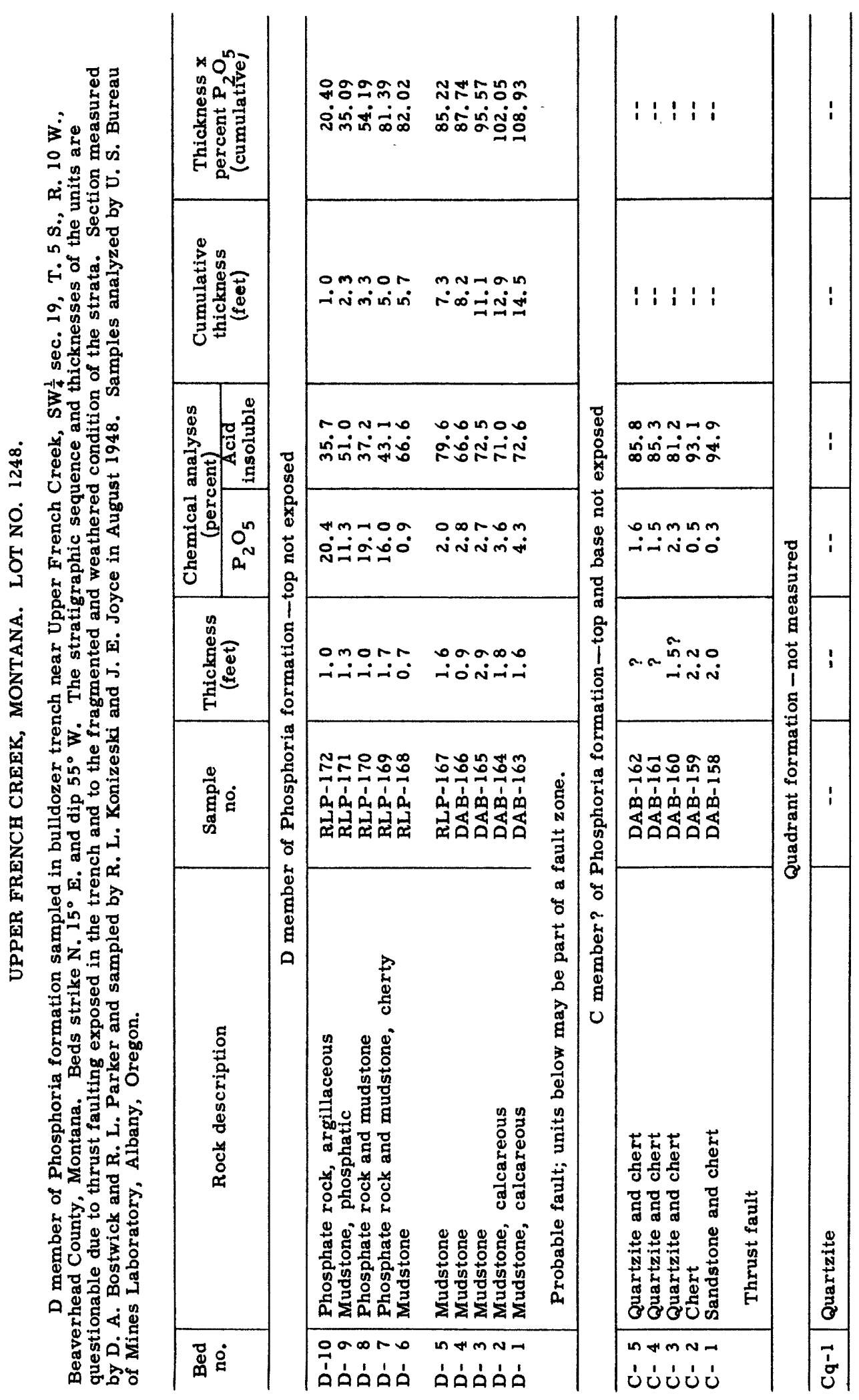




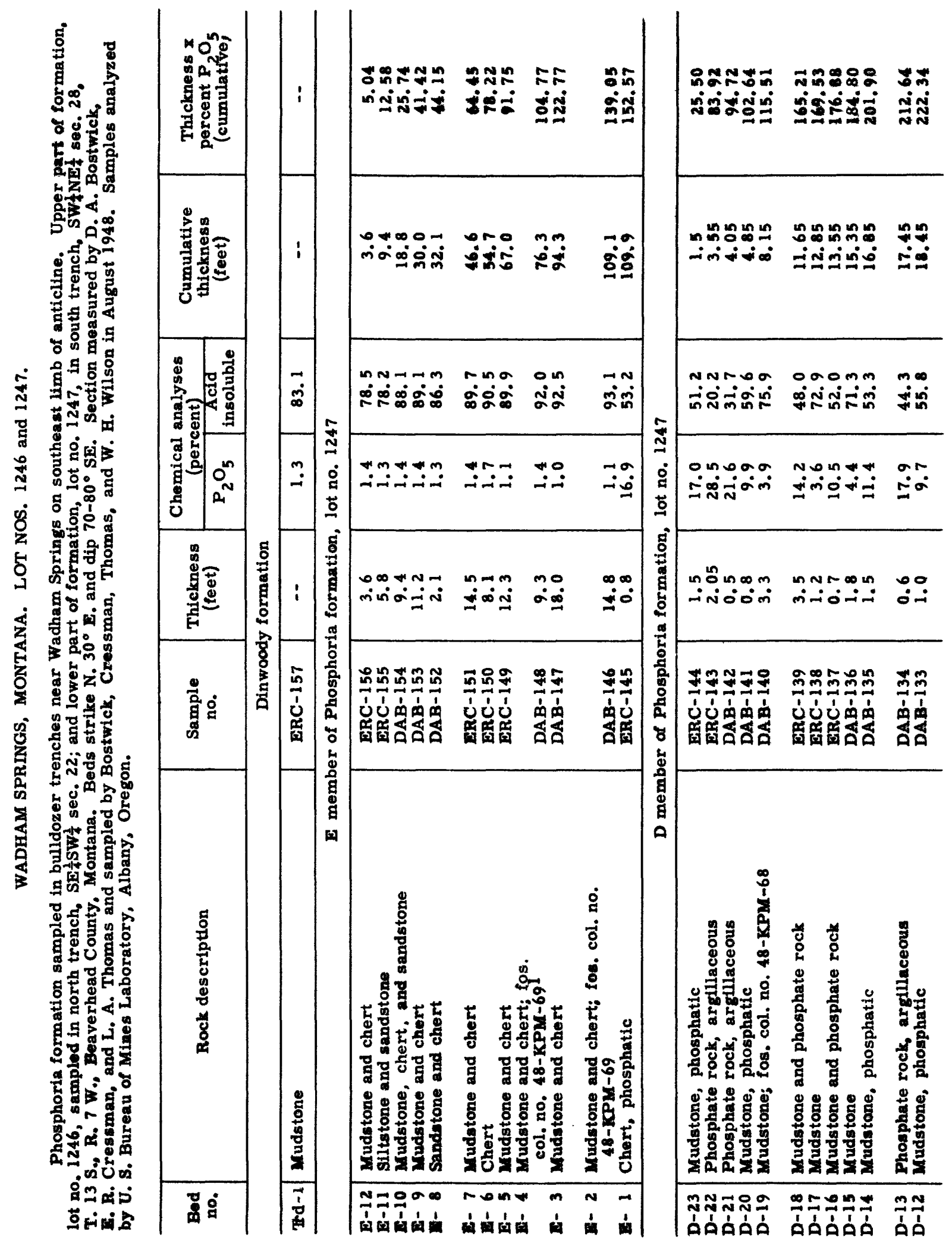




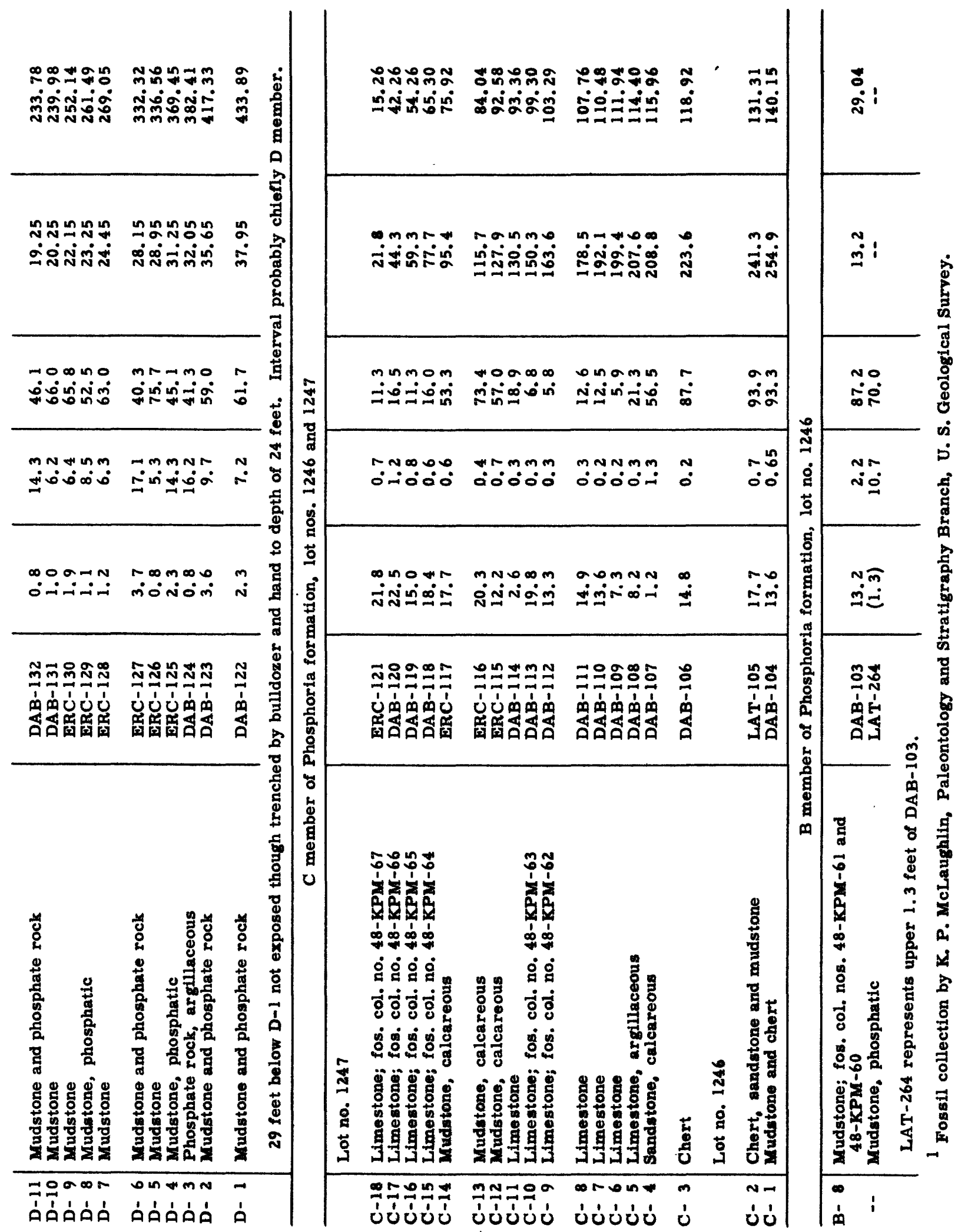




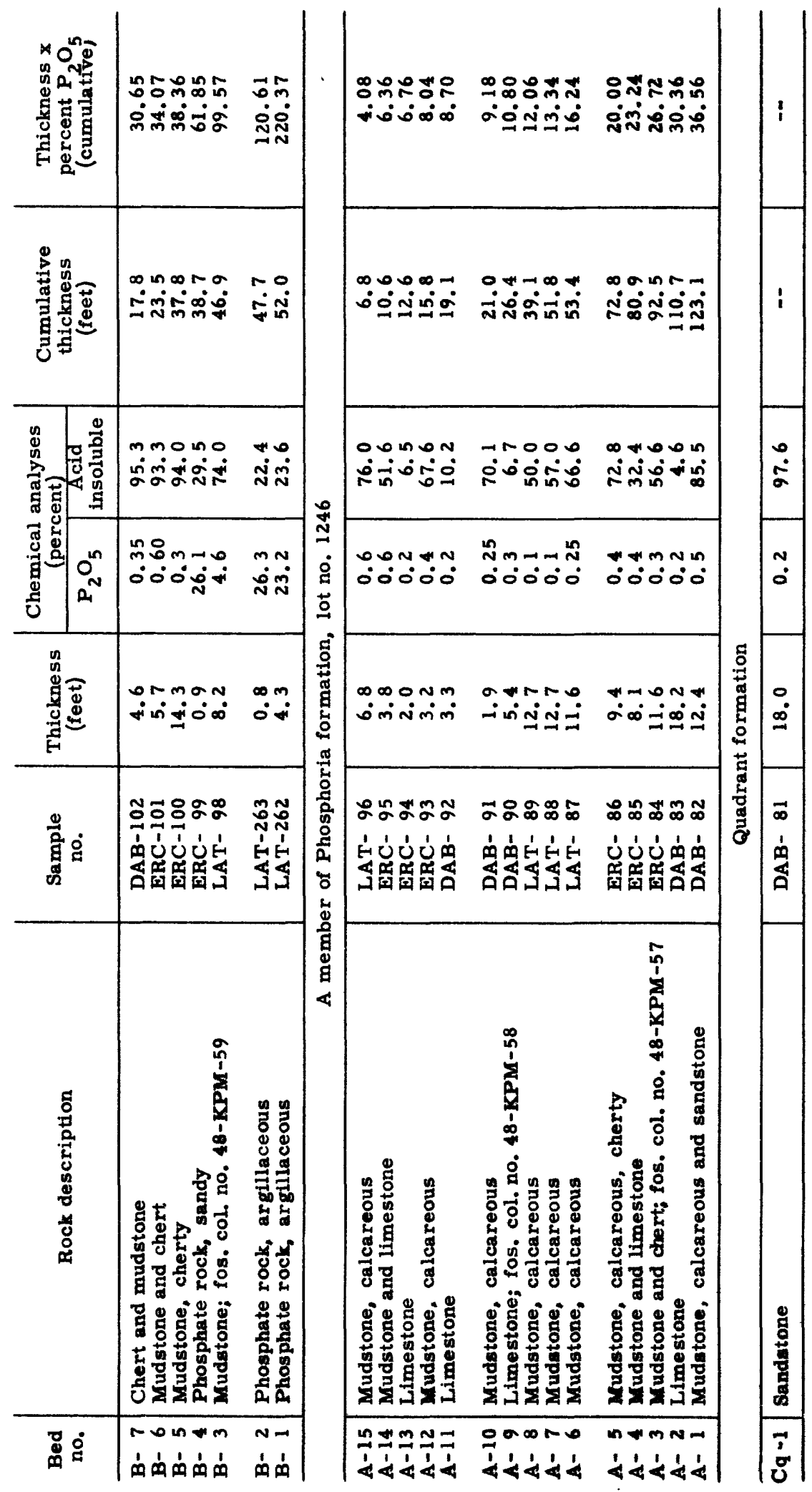




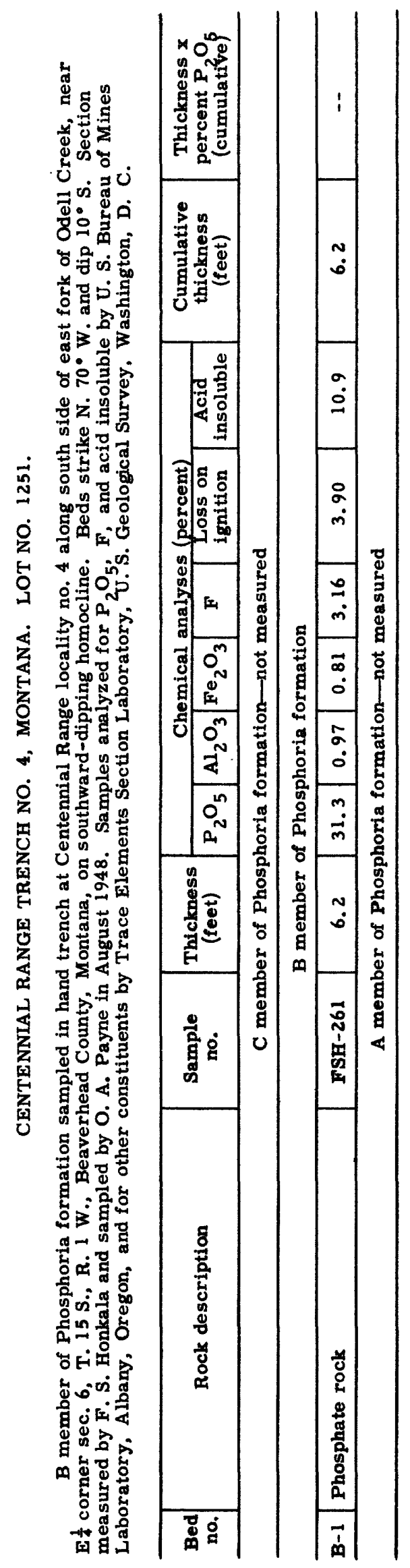




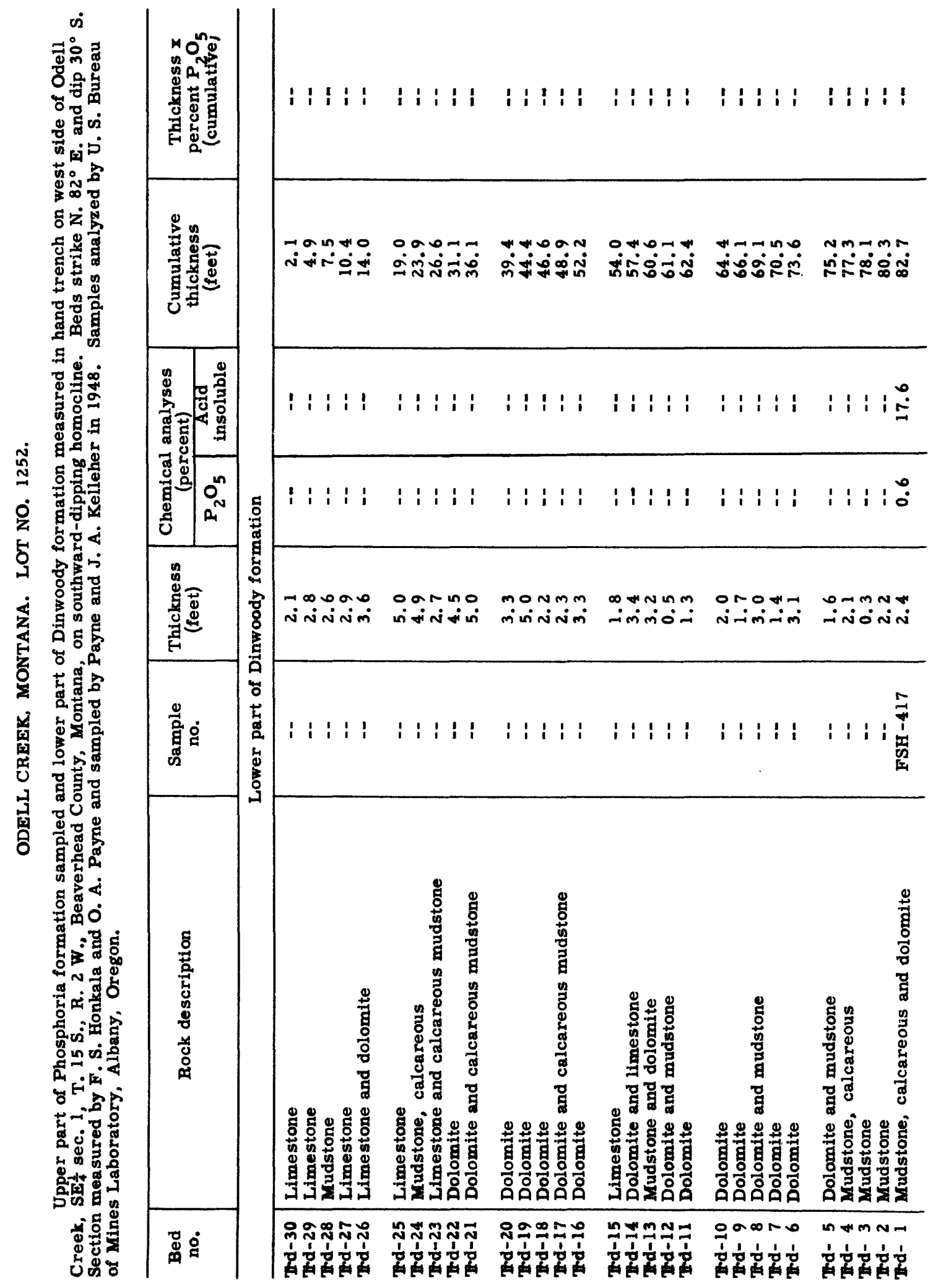




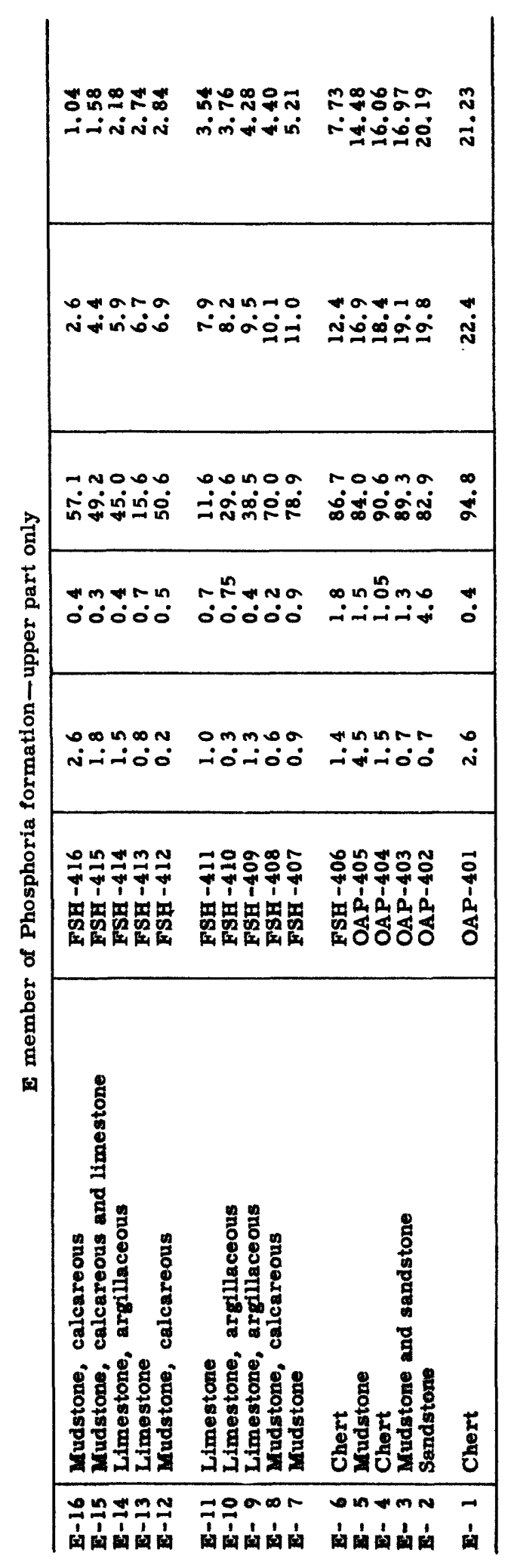




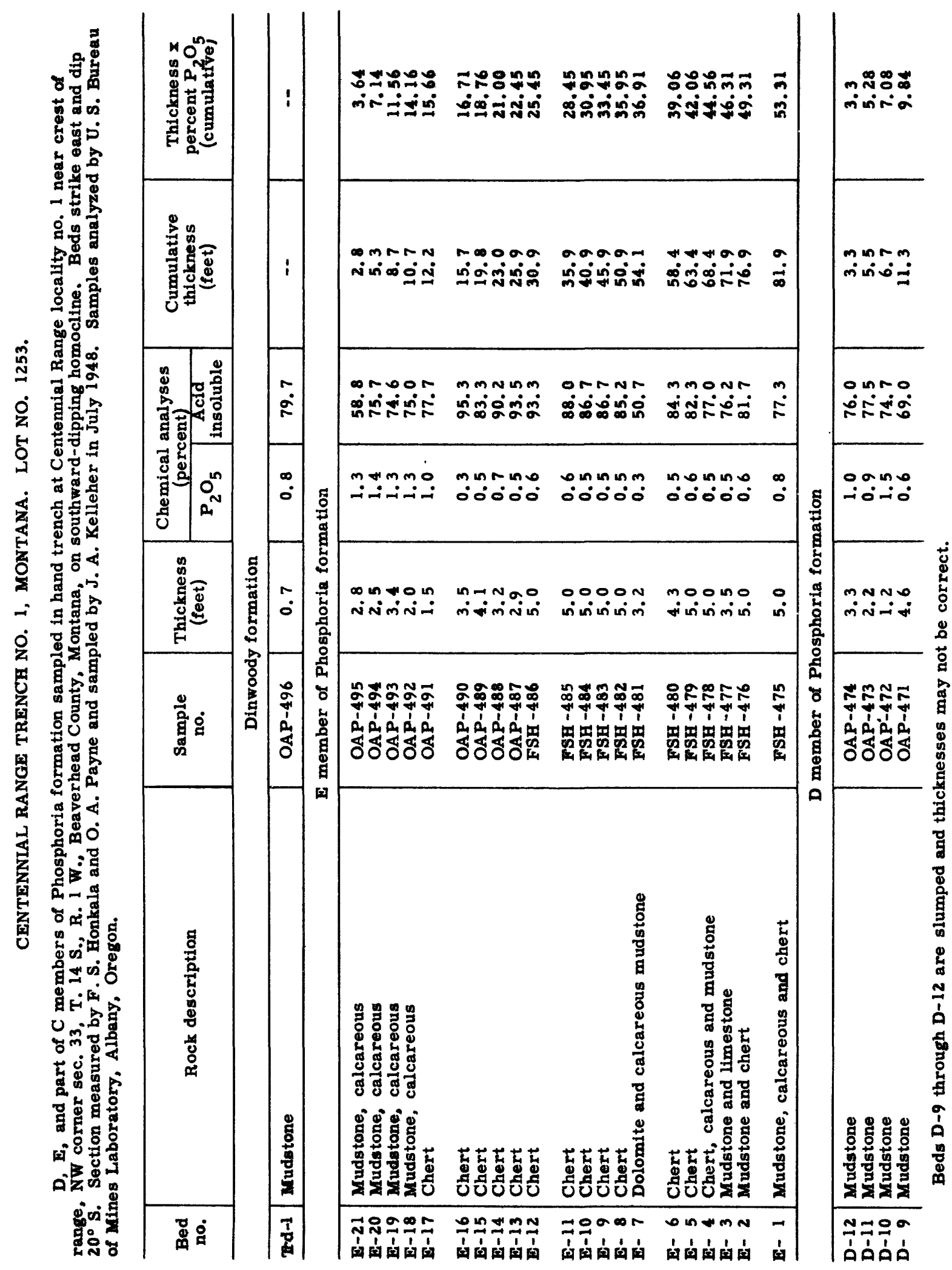




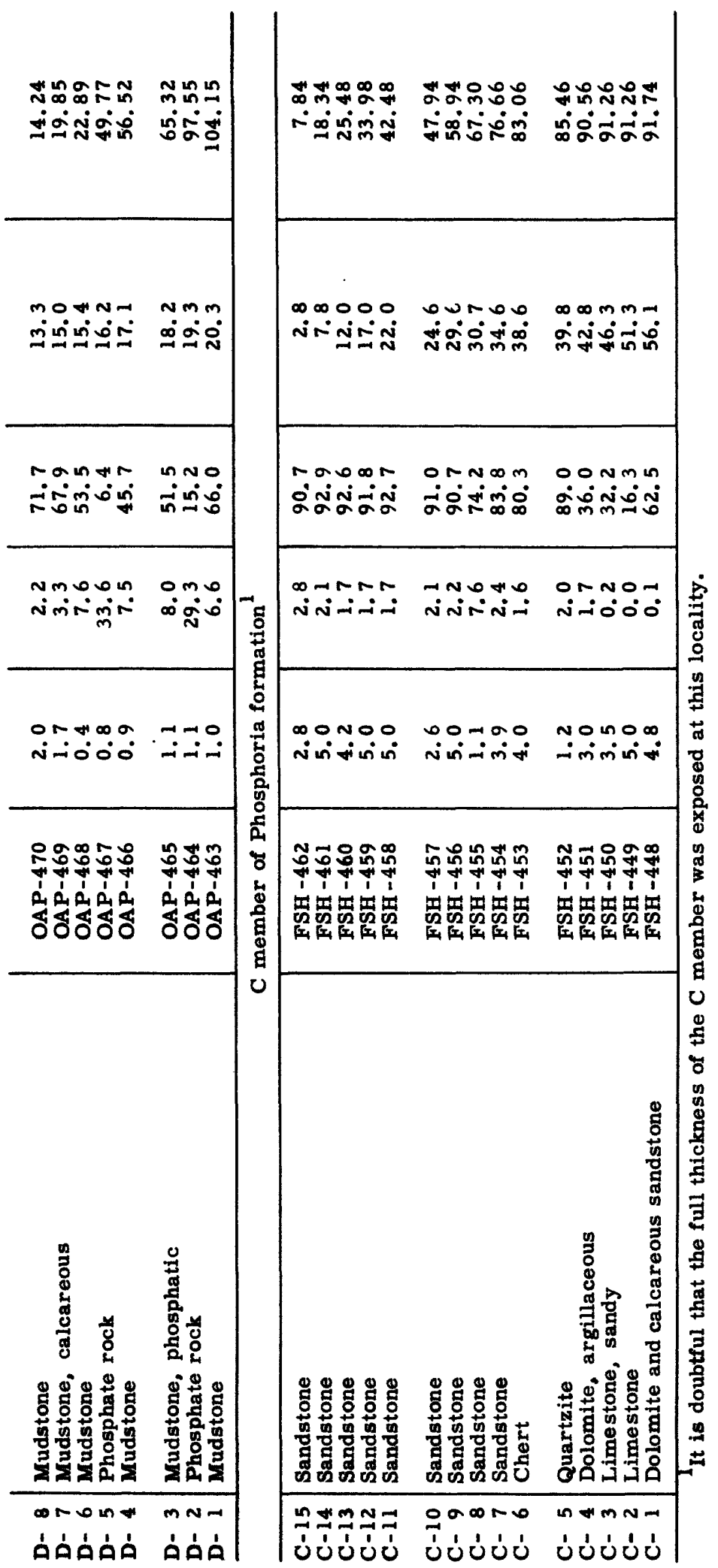




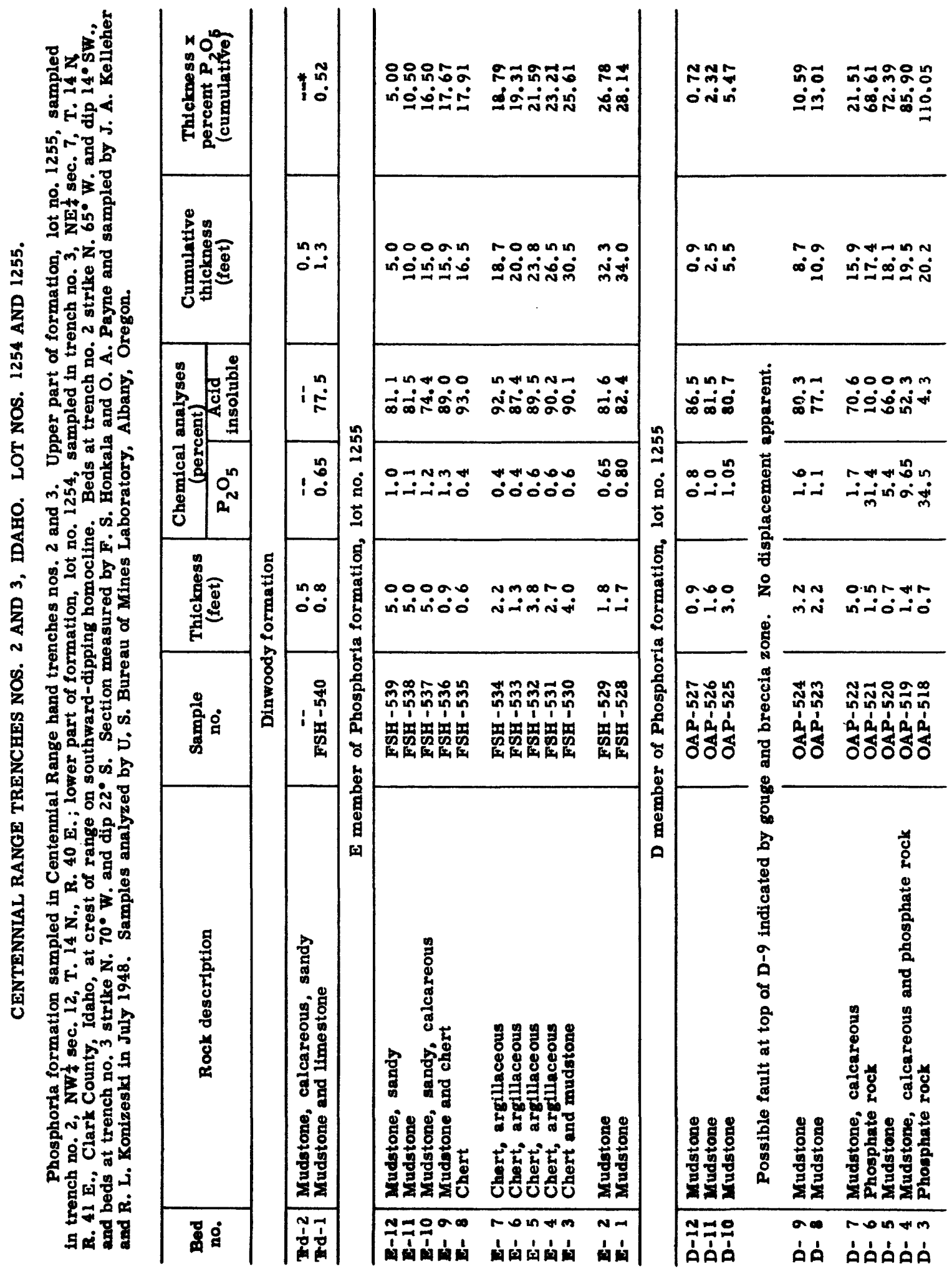




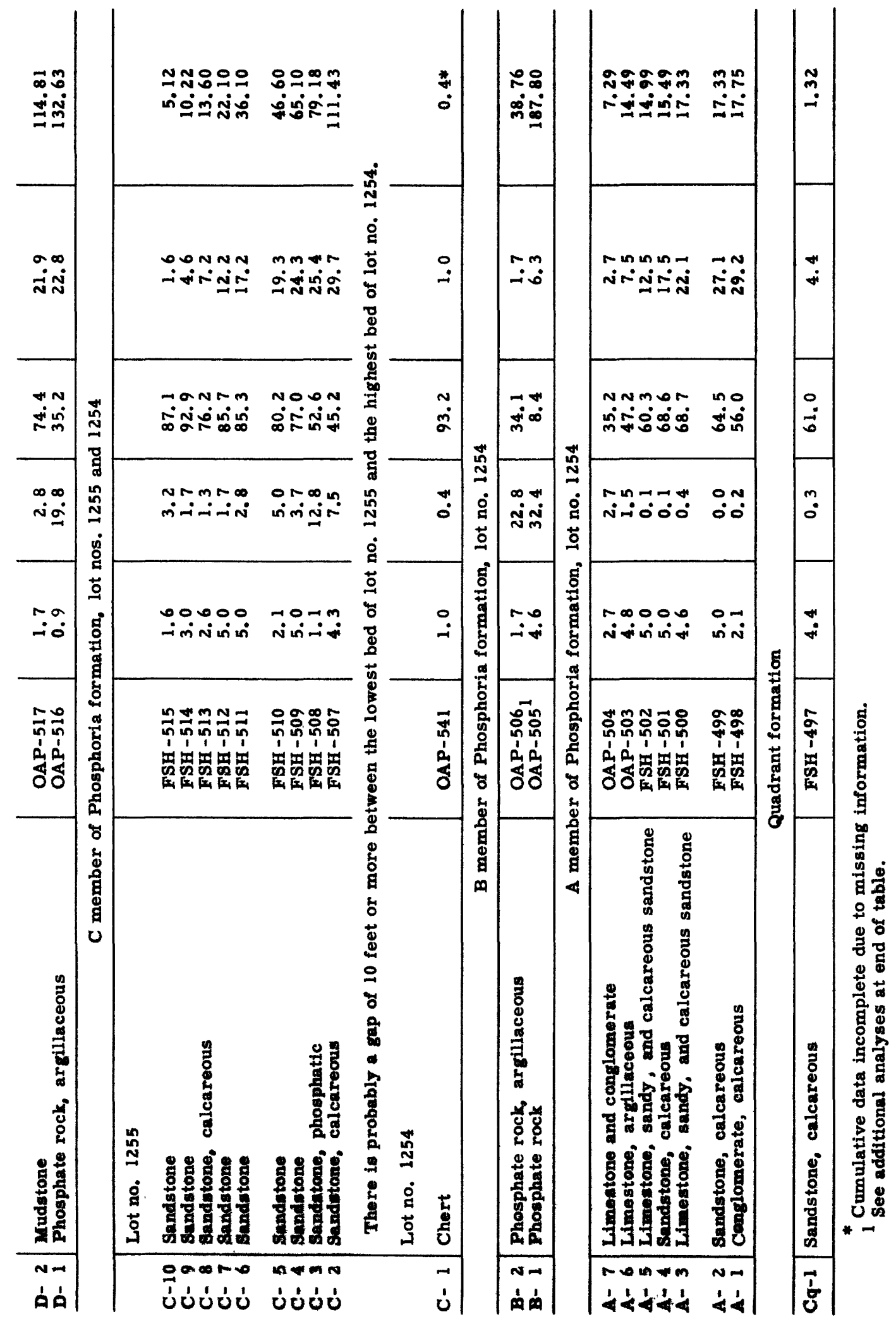




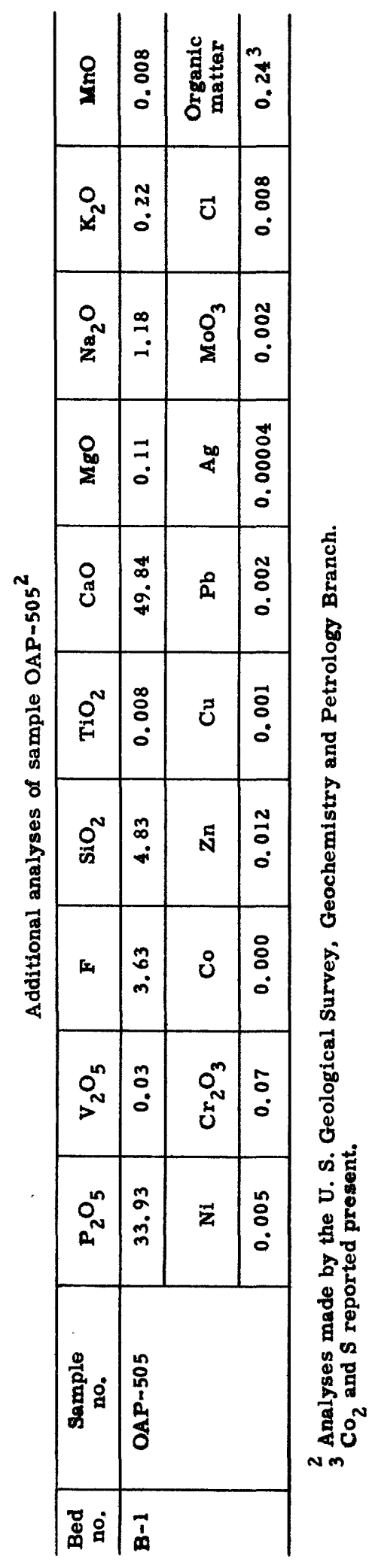



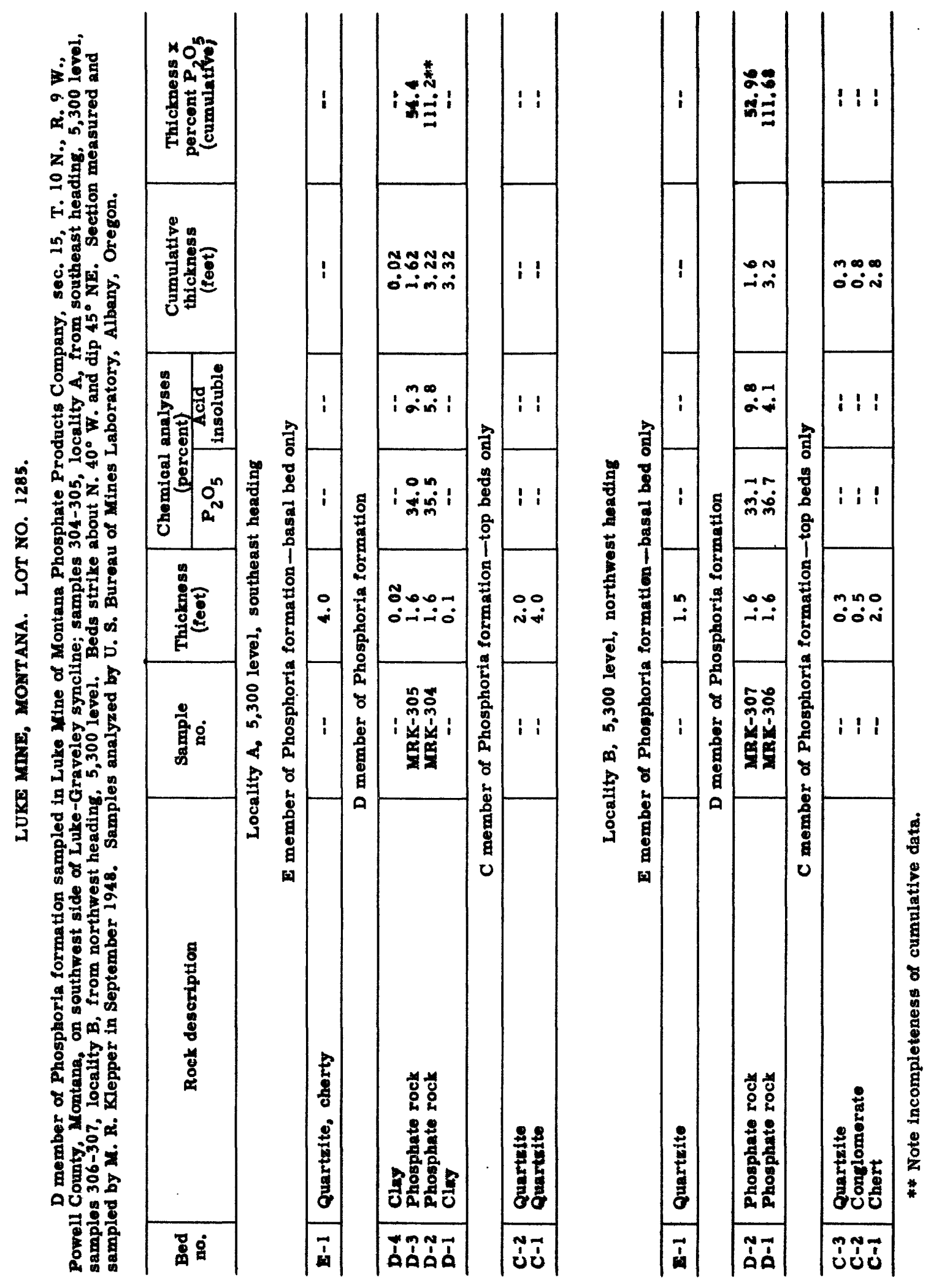